\title{
A Constituição de 1988 e a reforma política no Brasil: Lições de quatro momentos de votação
}

Eric Nogueira Andrade

\section{Eric Nogueira Andrade}

Mestrado em Ciência Política pela UFF e doutorando em Ciência Política do IESP-UERJ. Atualmente é pesquisador do Núcleo de Estudos sobre o Congresso (NECON) do IESP e do BraS-center (Brazilian research and studies).

Email: bismark_sa@hotmail.com

ORCID: 0000-0003-3509-7706

\begin{abstract}
Resumo
Eleições são o alicerce de toda democracia representativa. Curiosamente, grande parte dos políticos brasileiros demonstram grande insatisfação com as regras eleitorais vigentes no país desde a redemocratização em 1988 e propõem recorrentemente um conjunto de propostas de alterações. É sabido que o sistema eleitoral de uma democracia não se altera com facilidade. Uma combinação de elementos precisa estar presente. No caso brasileiro as propostas de modificar o sistema eleitoral foram em quatro momentos sistematicamente rejeitadas, ainda que muitas outras mudanças na legislação eleitoral tenham sido aprovadas ao longo das sucessivas legislaturas. Para a compreensão desse processo, este trabalho focou parte do seu esforço inicial em apresentar duas possíveis abordagens teóricas que enxergam reformas a partir dos seus efeitos interpartidário e intrapartidário. Também foram objeto de análise quatro comissões especiais de reforma política que constituem a base dos debates sobre a reforma eleitoral na Câmara dos Deputados. Essas comissões propuseram e aprovaram importantes alterações na legislação eleitoral do Brasil. O exame comparativo dessas comissões pode lançar luz sobre parte dos questionamentos acerca das inúmeras alterações ocorridas. Por fim, examino quatro momentos em que uma alternativa ao sistema eleitoral foi posta em votação. Os resultados indicam que o longo processo de reforma no Brasil pós-1988 teve como grande objetivo a redistribuição da correlação de forças partidária, restringindo o acesso de pequenos partidos ao parlamento, e limitando, ainda que levemente, a personalização do sistema eleitoral, afetando diretamente a proporcionalidade dos resultados eleitorais das eleições de 2018. Também foi possível demonstrar que o sistema eleitoral não se alterou devido à clara falta de acordo entre os grandes partidos. A cada proposta votada, os maiores partidos se revezaram na liderança das coalizões que as vetaram. O artigo combina teoria, analise cronológica e comparação para alcançar os seus objetivos.
\end{abstract}

Palavras Chaves: Reforma política; Sistema eleitoral; Sistema partidário; estudos legislativos; Crise política. 

VOTAÇÃO

Eric Nogueira Andrade

\section{Abstract}

Elections lie at the foundation of any democracy. Curiously, most Brazilian politicians show great dissatisfaction with the electoral rules in use in the country since the redemocratization in 1988 and repeatedly propose a set of proposals for changes. It is well known that the electoral system of a democracy does not change easily. A combination of elements must be present. In the case of Brazil, the proposals to reform the electoral system were systematically rejected at four distinct moments, even though many other changes in the electoral legislation were approved during the successive legislatures. To understand this process, this paper focused part of its initial effort on presenting two possible theoretical approaches that view reforms from their inter-party and intra-party effects. I also analyzed four special commissions on political reform that form the basis of the debates on electoral reform in the House of Representatives. These commissions proposed and approved important changes in Brazil's electoral legislation. A comparative examination of these commissions can clarify some of the questions about the numerous changes that occurred. Finally, I examine four moments in which an alternative electoral system was put to the vote. The results indicate that the long reform process in Brazil after 1988 had as a major objective the redistribution of the correlation of party forces, restricting the access of small parties to parliament, and limiting, even if slightly, the personalization of the electoral system, directly affecting the proportionality of the electoral results of the 2018 elections. It has also been possible to demonstrate that the electoral system has not changed due to the clear lack of agreement between the major parties. For each proposal voted, the major parties alternated in leading the coalitions that vetoed them. The article combines theory, chronological analysis and comparison to achieve its objectives.

Keywords: Political reform; Electoral system; Party system; legislative studies; Political crisis.

\section{Resumen}

Las elecciones son la base de toda democracia representativa. Curiosamente, gran parte de los políticos brasileños muestran un gran descontento con las reglas electorales vigentes en el país desde la redemocratización de 1988 y proponen recurrentemente un conjunto de propuestas de cambio. Es sabido que el sistema electoral de una democracia no cambia fácilmente. Debe haber una combinación de elementos. En el caso brasileño, las propuestas de modificación del sistema electoral fueron sistemáticamente rechazadas en cuatro ocasiones, a pesar de que muchos otros cambios en la legislación electoral fueron aprobados a lo largo de sucesivas legislaturas. Para entender este proceso, este trabajo centró parte de su esfuerzo inicial en presentar dos posibles perspectivas teóricas que contemplan las reformas desde sus efectos interpartidistas e intrapartidistas. También analizamos cuatro comisiones especiales sobre la reforma política que constituyen la base de los debates sobre la reforma electoral en la Cámara de Representantes. Estas comisiones propusieron y aprobaron importantes cambios en la legislación electoral de Brasil. Un examen comparativo de estas comisiones puede clarificar algunas de las incógnitas sobre los numerosos cambios que se realizaron. Por último, examino cuatro momentos en que se sometió a votación un sistema electoral alternativo. Los resultados indican que el largo proceso de reforma en Brasil posterior a 1988 tuvo como objetivo principal la redistribución de la correlación de fuerzas partidarias, restringiendo el acceso de los partidos pequeños al parlamento, $y$ limitando, aunque sea levemente, la personalización del sistema electoral, afectando directamente la proporcionalidad de los resultados electorales de las elecciones de 2018. También se pudo demostrar que el sistema electoral no cambió debido a la clara falta de 
acuerdo entre los grandes partidos. Ante cada propuesta votada, los principales partidos se turnaron para liderar las coaliciones que las vetaron. El artículo combina la teoría, el análisis cronológico y la comparación para lograr sus objetivos.

Palabras Clave: Reforma política; Sistema electoral; Sistema de partidos; Estudios legislativos; Crisis política.

\section{Introdução}

Regras eleitorais são fundamentais para a viabilidade de uma disputa democrática saudável. Mas além disso, são elas que moldam o modo pelo qual as campanhas ocorrem. Assim, políticos profissionais precisam estar atentos a cada variação das regras e se antecipar aos seus impactos. Fossem as regras outras e talvez George W. Bush não tivesse sido reeleito nas eleições norte americanas de 2000, ou, em outro exemplo, o PSL (Partido Social Liberal), nas eleições de 2018, mesmo sendo o partido mais votado, não tivesse conquistado o segundo lugar em número de cadeiras no Legislativo brasileiro. Dada essa relevância, regras eleitorais são objeto de grande interesse por parte de acadêmicos em todo o mundo.

A discussão sobre alterações na legislação eleitoral é bastante recorrente no Brasil. Comissões de reforma política foram instaladas em seis das nove legislaturas da Câmara baixa pós-Constituição de 1988. Das três restantes, uma existiu no período da elaboração da Constituição, outra se ocupou da revisão da Constituição, em 1993, e outra, em 2007, realizou a votação da proposta da Legislatura anterior, que havia elaborado um projeto amplo em 2003. Ou seja, até a presente pesquisa nenhuma legislatura, pós-regime militar, deixou de tratar da temática da reforma eleitoral.

É importante destacar que a Constituição de 1988 foi bastante prudente na escolha das instituições que regulamentariam a representação democrática depois de longo período de ditadura militar. Em larga medida ela readotava o que podemos chamar de: a tradição republicana brasileira, desde 1934 . O sistema de governo se manteve presidencial, com bicameralismo e sistema eleitoral proporcional por lista aberta. Entretanto, ela já nasceu com a promessa de uma revisão, marcada para 1993, cinco anos depois da sua promulgação. Ou seja, a temática da reforma das instituições políticas brasileiras já nasce no ato da promulgação da nova Constituição e com data marcada.

Ainda assim, o debate não se encerrou com a revisão constitucional de 1993 . Em contraste, o que observamos foi um constante processo de reformas, apelidado por Fleischer (2004; 2014) de: "uma história sem fim". As justificativas para o retorno desse debate vão desde críticas sobre o seu funcionamento em termos de governabilidade (CINTRA, 2008), a alterações pontuais (SANTOS, 2006) e propostas "semipresidencialistas" (AMORIM NETO, 2006). Em decorrência disso, políticos e acadêmicos se empenharam no exame e debate do funcionamento institucional pós-1988 e das possíveis alternativas. Assim cresceram as dúvidas sobre o sistema eleitoral e também sobre outras especificidades do sistema político brasileiro.

O artigo se inicia com uma abordagem contextual sobre como a temática da reforma política foi tratada por cada legislatura desde a Constituição de 1988. Apresento, ainda nesta primeira sessão, um arcabouço conceitual que nos auxilie a caracterizar e entender as diferentes possibilidades de processos de reformas. Em sequência, conduzo uma detalhada análise de quatro comissões especiais de reforma política instaladas na Câmara dos Deputados. Também examino e comparo os resultados de quatro momentos em que o 

VOTAÇÃO

Eric Nogueira Andrade

Congresso votou e negou inúmeras propostas de reformar o sistema eleitoral. O método comparative process tracing serviu como a base desta pesquisa, a fim de entender diferenças e similitudes que possam ajudar a esclarecer e identificar padrões. O objetivo deste estudo é compreender o processo de reforma eleitoral no Brasil pós-1988 e em que medida os políticos profissionais dominaram o processo e almejaram as reformas propostas. A fim de robustecer a análise, foram incluídos tanto os episódios em que as propostas foram aprovadas quanto as tentativas frustradas. $O$ estudo abrangeu propostas de reformas amplas e com efeito interpartidário, como reformas no nível micro e de efeito intrapartidário.

\section{A reforma política entre as diferentes Legislaturas pós-88}

Para além do marco democrático e de reabertura política, a promulgação da Constituição de 1988 marcou também o início de um embate acadêmico, acerca da viabilidade do sistema político inaugurado, que perdurou por toda a década de 1990 (LAMOUNIER, 1991, 1992, 1994; MAINWARING, 1991; 1997; FIGUEIREDO \& LIMONGI, 1999; SANTOS, 1999; 2003 dentre outros). Este embate teve o seu ponto alto no plebiscito de 1993, que deu ao eleitor a oportunidade de alterar o sistema de governo, mas também foi marcado por trabalhos empíricos de mais de uma geração de pesquisadores que se esmeraram sobre o funcionamento das relações Executivo-Legislativo no Brasil. Isso não significou, contudo, o fim de tentativas ambiciosas de reformar as instituições políticoeleitorais.

Uma vez solucionada a opção de sistema de governo, com a manifestação direta dos cidadãos chancelando a adoção do presidencialismo, manteve-se as dúvidas sobre o sistema eleitoral (AMES, 2001; 2003; CINTRA, 2005; 2007; FLEISCHER, 2005; 2014; PEREIRA; MUELLER, 2006). Essas duas opções institucionais foram destacadas por Abranches (1988), na sua famosa crítica ao sistema político que se desenhava na constituinte, que teve como objetivo alertar para os problemas de um desfecho que favorecesse o status quo institucional anterior ao regime militar. A junção de presidencialismo com multipartidarismo foi então descrita e referenciada pelo termo "presidencialismo de coalizão". As críticas, já naquela época, lançavam dúvidas sobre um quesito em específico, a governabilidade de governos presidenciais com multipartidarismo, e um dos principais alvos da crítica foi justamente o sistema eleitoral. Não obstante, uma série de reformas na legislação eleitoral foi levada a cabo, mas sem tocar na matriz do sistema eleitoral.

Assim, o país vive sob um arranjo institucional que desde a sua fundação experimenta constantes debates sobre eventuais reformas. Um dado relevante foi que todas as legislaturas desde 1988 se empenharam na temática da reforma política, criando comissões especiais e sugerindo e votando projetos de leis e propostas de emendas constitucionais.

Tabela 1 - Comissões especiais de reforma política.

\begin{tabular}{|c|c|c|c|c|}
\hline & Projetos & Resultados & Legenda & Votação \\
\hline Constituição de 1988 & & & & 1988 \\
\hline Revisão constitucional & & & & 1993 \\
\hline Comissão especial de 1995 & PL 1670/1989 & Lei 9096/1995 & Lei dos partidos & 1995 \\
\hline $\begin{array}{l}\text { Comissão especial de } 2001 \\
\text { Comissão especial de } 2003\end{array}$ & $\begin{array}{l}\text { PL 5268/2001 } \\
\text { PL 1712/2003 } \\
\text { PL 2679/2003 }\end{array}$ & $\begin{array}{l}\text { Rejeitada } \\
\text { Rejeitada } \\
\text { Rejeitada }\end{array}$ & & $\begin{array}{l}2007 \\
2007\end{array}$ \\
\hline Comissão especial de 2011 & Obstruída & & & \\
\hline
\end{tabular}



VOTAÇÃO

Eric Nogueira Andrade

\begin{tabular}{lllll} 
Comissão especial de 2015 & PL 5735/2013 & Lei 13165/2015 & minireforma & 2015 \\
& PEC 182/2007 & EC 91/2016 & janela partidária & \\
Comissão especial de 2016 & PL 8612/2017 & Lei 13488/2017 & minireforma & 2017 \\
& PL 8703/2017 & Lei 13487/2017 & $\begin{array}{l}\text { minireforma } \\
\text { Coligação, Cláusula } \\
\text { de desempenho }\end{array}$ & \\
& PEC 282/2016 & EC 97/2017 & & \\
& PEC 77/2003 & Rejeitada & & \\
Comissão especial de 2021 & Em andamento & & & \\
\hline
\end{tabular}

Fonte: Elaboração própria com dados da Câmara dos Deputados.

Com isso, uma estratégia metodológica que pode ser útil para entendermos esse longo processo de reformas, é compararmos as diferentes legislaturas e comissões a fim de elucidar padrões e diferenças. Dessa forma, poderemos classificar as diferentes tentativas de reformas e analisar o que esteve em jogo, tanto para as forças partidárias, quanto para políticos e para a sociedade. O primeiro padrão facilmente observável, foi que todas as comissões de reforma política trataram de três leis especificas: a lei n 4.737/1965 (Código eleitoral); a lei n 9.096/1995 (Lei dos partidos); e a lei n 9.504/1997 (Lei das eleições). A única comissão especial que tratou de apenas uma dessas três leis foi, por motivos óbvios, a comissão de 1995, que elaborou a lei dos partidos. Todas as demais sugeriram um conjunto de alterações que afetavam essas três leis e somente no caso das comissões de 2015 e 2017 foram sugeridas, adicionalmente, emendas constitucionais. Portanto, é razoável dizer que o termo reforma política, para o Poder Legislativo, se trata de alterações na legislação eleitoral.

Ainda assim, não é possível examinarmos todas as legislaturas como iguais no que concerne ao tópico da reforma política. Como é possível observar a partir da tabela 1, as duas primeiras legislaturas (48, entre 1987 à 1991, e a 49, entre 1991 à 1995) trataram da constituinte e da revisão constitucional, respectivamente. A 53a Legislatura (entre 2007 à 2011), atuou apenas na votação de propostas produzidas pelas comissões de 2001 e 2003. Por fim, a 53a Legislatura (entre 2011 à 2015) instalou a comissão de 2011 que foi obstruída sem que se produzisse qualquer proposta e organizou, depois das manifestações de 2013, um grupo de trabalhos que produziria o relatório Vaccarezza ou PEC 352/2013, que se tornou a base das discussões na comissão especial de 2015. Tampouco é possível tratarmos todas as comissões especiais como iguais, visto que as comissões de 1995 e 2001 não trataram de sistemas eleitorais, tópico fundamental nas demais comissões. Proponho, em razão dessas dificuldades, tratarmos em profundidade de apenas quatro comissões especiais; 2003; 2011; 2015; e 2016. Todas elas tiveram longas sessões de debates e abordaram temas similares que marcaram a temática da reforma política na Câmara dos Deputados do Brasil. Apesar disso, não deixarei de incluir dados e análises que cubram todo o período democrático pós-Constituição de 1988. Não tratarei das comissões instaladas no Senado, pois elas trabalharam, em geral, em conjunto com as discussões na Câmara e foram de menor intensidade.

Para analisarmos processos de reformas eleitorais, primeiro devemos considerar um conjunto de questões que nos ajudam a classificar diferentes possibilidades de reformas. 0 primeiro passo, é ponderar sobre quais atores estiveram à frente do processo: quem teve o poder de escolher as novas regras eleitorais? Que ator político esteve à frente do processo? Em que medida este grupo político foi constrangido por outros atores? A literatura internacional se divide em duas grandes correntes de pensamento ao tratar desses 
questionamentos. A primeira, muito influenciada pela teoria da escolha racional, considera que os políticos sempre dominam o processo de reformas e que as reformas se resumem a um jogo de interesses de elites que formulam o seu cálculo com base no que esperam obter em termos de ganhos políticos (COX, 1997; BOIX, 1999; COLOMER, 2004a; BOWLER ET ALL, 2006; BENOIT, 2004, 2007). A segunda, permite um alcance maior de atores com a capacidade de envolvimento e interesses nas reformas, considerando a reforma como resultado de fatores contingentes e inerentes (SHUGART, 2001a; 2001b; SHUGART; WATTENBERG, 2001b; KATZ, 2005; NORRIS, 2010; RENWICK, 2010).

Ainda assim, segundo Shugart (2001b: 25), duas dimensões são cruciais para compreendermos reformas nas regras eleitorais: a dimensão interpartidária e a dimensão intrapartidária. Enquanto a primeira pode ser encarada de forma ampla, focando na distribuição de ganhos entre as forças partidárias, a segunda pode ser analisada no contexto micro, em referência à distribuição do poder dentro dos partidos. Assim, os estudos voltados para variações de sistemas eleitorais têm se desenvolvido, principalmente, em análises que encaram tanto a reforma a partir de mudanças interpartidárias (RAE, 1967; LIJPHART, 1994), como a partir de alterações intrapartidárias (CAREY; SHUGART, 1995; SHUGART, 2001a, 2001b), este último, mais recente, com o objetivo de traçar possíveis padrões de incentivos para candidatos e legisladores.

A partir disso, adotarei uma tipologia de reformas desenvolvida em outro trabalho (ANDRADE, 2019) que servirá de base para o propósito de análise do processo brasileiro de reformas ao longo de todo o período democrático recente, na dimensão interpartidária. Com isso, considero que múltiplos atores podem intervir no processo de reformas e, para o caso brasileiro, quatro categorias foram observadas: reforma redistributiva; reforma eficiente; decisão judicial; e democracia direta. Além disso, abordarei sobre uma estrutura conceitual (RENWICK; PILET, 2016) que define variações de reformas com base em alterações intrapartidárias, como sugere o quadro abaixo:

Quadro 1 - Estrutura conceitual com sete dimensões de análise sobre reformas intrapartidárias. A expressão de preferências entre os candidatos

1- O número de candidatos que o eleitor pode votar

2- Se permite ao eleitor expressar dois, três ou inúmeros níveis de preferência

3- Se possibilita que o eleitor expresse múltiplas preferências somente entre candidatos do mesmo partido ou igualmente de partidos diferentes

4- Até que ponto os eleitores possuem um efetivo grau de escolha intrapartidária

5- A distância entre eleitores e candidatos. A magnitude dos distritos

O impacto das preferências entre os candidatos

6- O grau em que o voto no candidato determina a ordem em que os candidatos serão eleitos

7- O grau de pooling, expressão que aponta para o quanto um candidato pode ser beneficiado pelo voto de outros candidatos do mesmo partido

Fonte: Elaboração própria com base nos estudos de Renwick; Pilet 2016.

Se considerarmos que os políticos estiveram à frente de um processo de reforma, duas categorias podem nos informar sobre o perfil desse domínio por parte dos políticos profissionais: reformas redistributivas e eficientes. Ambas foram classificadas por Renwick 

VOTAÇÃO

Eric Nogueira Andrade

(2010) como "imposição da elite majoritária" e "acordo de elites" e remetem à ideia presente do texto de Tsebelis (1990: 104) sobre as relações sociais em sociedades capitalistas. Para Tsebelis, tais sociedade concebem instituições que são, ou ao menos podem ser analisadas, como redistributivas ou eficientes. A primeira, melhora a condição de um grupo da sociedade sob o custo de outros, enquanto a segunda melhora (com respeito ao status quo) a condição de todos (ou quase todos) os indivíduos ou grupos dentro da sociedade. Assim, propostas sobre a adoção de cláusulas de desempenho, ou de barreira, são perfeitos exemplos de reformas do tipo redistributivas, uma vez que serão benéficas para uns em detrimento de outros, que não alcançarem a barreira. Por outro lado, a instituição de prazos para filiação partidária a fim de se tornar candidato por um determinado partido, é o perfeito exemplo de uma reforma do tipo eficiente, já que a regra será aplicada a todos sem distinção.

As decisões judiciais, por outro lado, são a intervenção do poder judiciário nas leis eleitorais. No Brasil são conhecidas pelo termo "judicialização" da política, mas são destaque na literatura internacional de muitos países (MACIEL; KOERNER 2002; BOWLER; DONOVAN, 2008; RENWICK, 2010; BEHNKE et al., 2017, dentre outros).

Por fim, a democracia direta são um conjunto de instituições que permitem ao cidadão, apto a votar, decidir ou emitir sua opinião sobre temas diversos e que não forma o processo regular de tomada de decisão pré-estabelecido entre os três poderes (ALTMAN, 2010). Essa categoria constitui em apenas uma das possibilidades reservadas aos cidadãos. Como foi salientado em outro trabalho (ANDRADE, 2019), existe também a possibilidade de "imposição das massas", categorizada por Renwick (2010).

\section{As comissões especiais de reforma política}

Ao todo, sete comissões foram instaladas na Câmara dos Deputados, quatro comissões foram instaladas no Senado e o Executivo enviou uma proposta de reforma em 2009. Houve quatro momentos em que os projetos finais das comissões foram votados em Plenário. O judiciário, por sua vez, realizou quatro intervenções com decisões de constitucionalidade, afetando diretamente os debates de pelo menos duas comissões especiais instaladas na Câmara.

A primeira das comissões do Senado, em 1995, apresentou um relatório final que propunha oito propostas de emenda constitucional e três projetos de lei do Senado. Tais propostas não foram aprovadas pelo Plenário do Senado e, por força regimental, foram todas arquivadas em 1999. Na Legislatura seguinte, o Senado continuou avaliando o tema de forma mais dispersa e conseguiu aprovar e enviar para a Câmara do Deputados variadas propostas de lei nessa linha temática e que tiveram algum impacto nas discussões entre os deputados, embora não tenham logrado maior êxito. Apesar disso, não instalaram nenhuma comissão especial para apreciar o tema. Em 2005 uma comissão especial de reforma política foi formada, mas não apresentaram nenhum projeto ao final dos trabalhos. Em 20110 Senado instalou nova comissão especial concomitantemente com a Câmara dos Deputados e propuseram sete PECs e quatro projetos de lei. Por fim, uma última comissão foi criada em 2015, em resposta ao que havia sido produzido um mês antes por uma comissão de reforma política na Câmara dos Deputados. A comissão concluiu com o Projeto de Lei Complementar 75/15, um reexame do Projeto de Lei 5735/2013 enviada pela Câmara dos Deputados, a intitulada "minirreforma" de 2015.

A primeira das comissões instalada pelos deputados, ocorreu em 1995 e teve os seus debates aproveitados para a Lei dos Partidos Políticos (Lei $n^{\circ}$ 9.096/95). Intitulada "Comissão Especial da Reforma Política e Eleitoral", foi a primeira nessa linha temática 
Eric Nogueira Andrade

utilizando a expressão "reforma política" para manifestar o desejo de discutir a legislação político-eleitoral. A segunda se deu em 2001 e já se chamava "Comissão Especial de Reforma Política" (CEREFORM), para explicitar maior ênfase a expressão que se configurou basicamente como o "slogan" político em matéria de alterações político-eleitorais. Ao final da comissão houve a elaboração do Projeto de Lei $n^{\circ}$ 5268/2001. Ao avaliarmos o projeto de lei de 2001 é possível confirmar que ele não propunha grandes alterações na Legislação Eleitoral e sim pequenos ajustes.

Tanto as comissões do Senado, quanto as duas comissões especiais de 1995 e 2001, não serão tratadas por esta pesquisa com profundidade por não terem a proeminência no assunto da reforma como as quatro destacadas. Foi a partir de 2003 que os debates se intensificaram e o Senado, em mais de um momento, trabalhou em conjunto com a Câmara.

Todas as comissões especiais da Câmara, como dito anteriormente, à exceção da comissão de 1995, elaboraram alterações na Lei dos partidos políticos (lei n 9.096/95), na Lei das eleições (Lei $n^{\circ}$ 9.504/97) e no Código eleitoral (Lei $n^{\circ} 4.737 / 65$ ). A minirreforma de 2015 (lei no 13.165/2015), foi a primeira lei proveniente de uma comissão especial e que previa mudanças nessas três leis especificas, a conseguir a aprovação em plenário. As mudanças instituídas foram muito variadas e trataram, no geral, de especificidades de campanha. As alterações mais notáveis foram a redução do tempo de campanha e a criação de uma cláusula de desempenho para o candidato. A sua reformulação em 2016 foi efetuada especialmente por conta da proibição do financiamento privado de campanha.

Tabela 2 - Alterações nas leis n 9.096/95, n 9.504/97 e n 4.737/65 ao longo da $6^{\circ}$ República.

\begin{tabular}{|c|c|c|c|c|c|}
\hline $\begin{array}{l}\text { Lei dos } \\
\text { partidos/1995 }\end{array}$ & $\begin{array}{l}\mathrm{N}^{\circ} \text { de } \\
\text { alterações }\end{array}$ & $\begin{array}{l}\text { Lei das } \\
\text { eleições/1997 }\end{array}$ & $\begin{array}{l}\mathrm{N}^{\circ} \text { de } \\
\text { alteraçõos }\end{array}$ & $\begin{array}{l}\text { Código } \\
\text { eleitoral/1965 } \\
\end{array}$ & $\begin{array}{l}\mathrm{N}^{\circ} \text { de } \\
\text { alteraçõos }\end{array}$ \\
\hline Lei 9259/1996 & 4 & Lei 9709/1998 & 2 & Lei 7663/1988 & 2 \\
\hline Lei 9504/1997 & 6 & Lei 9840/1999 & 3 & Lei 7914/1989 & 10 \\
\hline Lei 9693/1998 & 4 & Lei $10406 / 2002$ & 1 & Lei 7977/1989 & 1 \\
\hline Lei $11459 / 2007$ & 3 & Lei $10408 / 2002$ & 14 & Lei $8037 / 1990$ & 11 \\
\hline Lei $11694 / 2008$ & 1 & Lei $10740 / 2003$ & 9 & Lei 8868/1994 & 33 \\
\hline Lei $12034 / 2009$ & 22 & Lei $11300 / 2006$ & 60 & Lei 9041/1995 & 1 \\
\hline Lei $12891 / 2013$ & 12 & Lei $12034 / 2009$ & 172 & LC 86/ 1996 & 1 \\
\hline Lei $12875 / 2013$ & 5 & Lei $12350 / 2010$ & 6 & Lei 9504/1997 & 30 \\
\hline Lei $13107 / 2015$ & 6 & Lei $12891 / 2013$ & 78 & Lei 9840/1999 & 1 \\
\hline Lei $13165 / 2015$ & 65 & Lei $12875 / 2013$ & 4 & Lei $10226 / 2001$ & 2 \\
\hline Lei $13488 / 2017$ & 4 & Lei $12976 / 2014$ & 3 & Lei $10732 / 2003$ & 2 \\
\hline Lei $13487 / 2017$ & 43 & Lei $13165 / 2015$ & 146 & Lei $12034 / 2009$ & 2 \\
\hline Lei $13831 / 2019$ & 15 & Lei $13107 / 2015$ & 1 & Lei $12891 / 2013$ & 6 \\
\hline Lei $13877 / 2019$ & 36 & Lei $13488 / 2017$ & 70 & Lei $13165 / 2015$ & 33 \\
\hline \multirow[t]{8}{*}{ Lei $14063 / 2020$} & 2 & Lei $13487 / 2017$ & 23 & Lei $13146 / 2015$ & 1 \\
\hline & & Lei $13473 / 2017$ & 1 & Lei $13105 / 2015$ & 11 \\
\hline & & Lei $13877 / 2019$ & 13 & Lei $13488 / 2017$ & 3 \\
\hline & & Lei $13878 / 2019$ & 3 & Lei $13877 / 2019$ & 3 \\
\hline & & & & Lei $13834 / 2019$ & 5 \\
\hline & & & & Lei $13999 / 2020$ & 1 \\
\hline & & & & MP 958/2020 & 1 \\
\hline & & & & MP 975/2020 & 1 \\
\hline
\end{tabular}


Fonte: Elaboração própria com dados da Câmara dos Deputados.

Se analisarmos as três leis objeto das comissões especiais, contudo, notamos que este conjunto de leis sofreu alterações ao longo de todo o período de suas vigências, em decorrência de diversas leis, como nos mostra a tabela 3. A lei n 12.034 de 2009, por exemplo, efetuou mais alterações na lei das eleições do que as leis aprovadas nas comissões de 2015 e 2016. A reforma dessas leis, portanto, não foi exclusividade das comissões. O que as comissões tiveram de diferente?

Como dito anteriormente, todas as comissões trataram dessas três leis que regulam as eleições no Brasil e apenas duas comissões, as primeiras, não trataram do sistema eleitoral. Isso porque somente a partir de 2003 que as comissões especiais passaram a debater sobre grandes alterações na legislação eleitoral. Ou seja, passaram a ter como objetivo o debate de reformas amplas, com a possibilidade de alterações constitucionais. Assim, a temática da reforma política passou a significar debates sobre reformas amplas, ainda que a aprovação fosse difícil.

\section{Os discursos dentro das quatro comissões especiais}

As quatro comissões especiais que proponho tratar com profundidade tiveram muitas similaridades, tanto no tempo de duração, quanto na intensidade dos debatesii e também nas propostas discutidas. Diferentemente das duas primeiras, as quatro em questão propuseram reformar o sistema eleitoral e tinham como objetivo debater reformas amplas na legislação eleitoral. Os seus debates são um importante material para entendermos o que esteve em negociação e quais tópicos tiveram maior relevância, ao longo de quase duas décadas de debate sobre a reforma eleitoral. A fim de utilizar este material, adoto para esta pesquisa um método de análise do discurso com o uso dos softwares IRAMUTEQ e R. Este método - método de classificação hierárquica descendente (CHD) - classifica os corpos textuais em classes de palavras com base na frequência no uso das palavras ao longo do texto. Essas classes, bem como os dados relativo à frequência das palavras, foram usadas para determinarmos a importância dos tópicos debatidos em cada comissão. 
Figura 1 - Discursos agregados por deputados. Comissão de 2003.

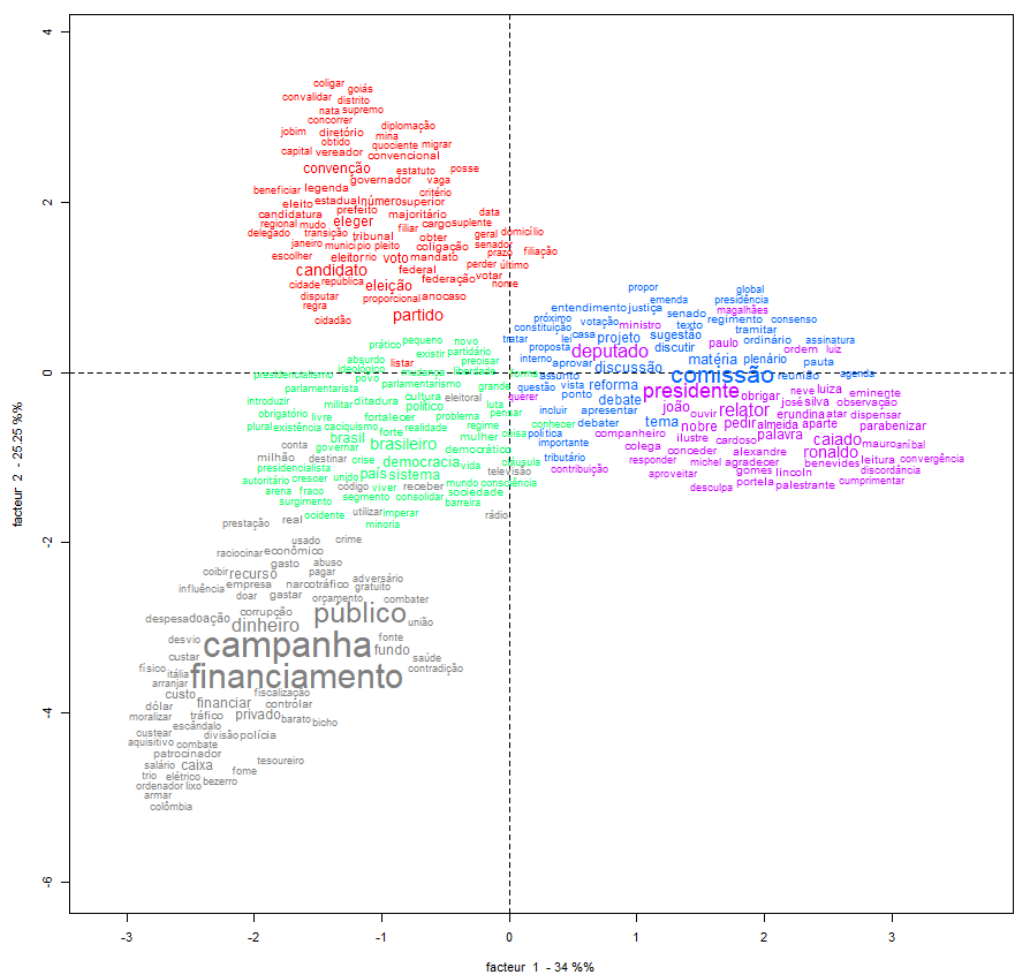

Fonte: Elaboração própria.

Figura 2 - Discursos agregados por deputados. Comissão de 2011.

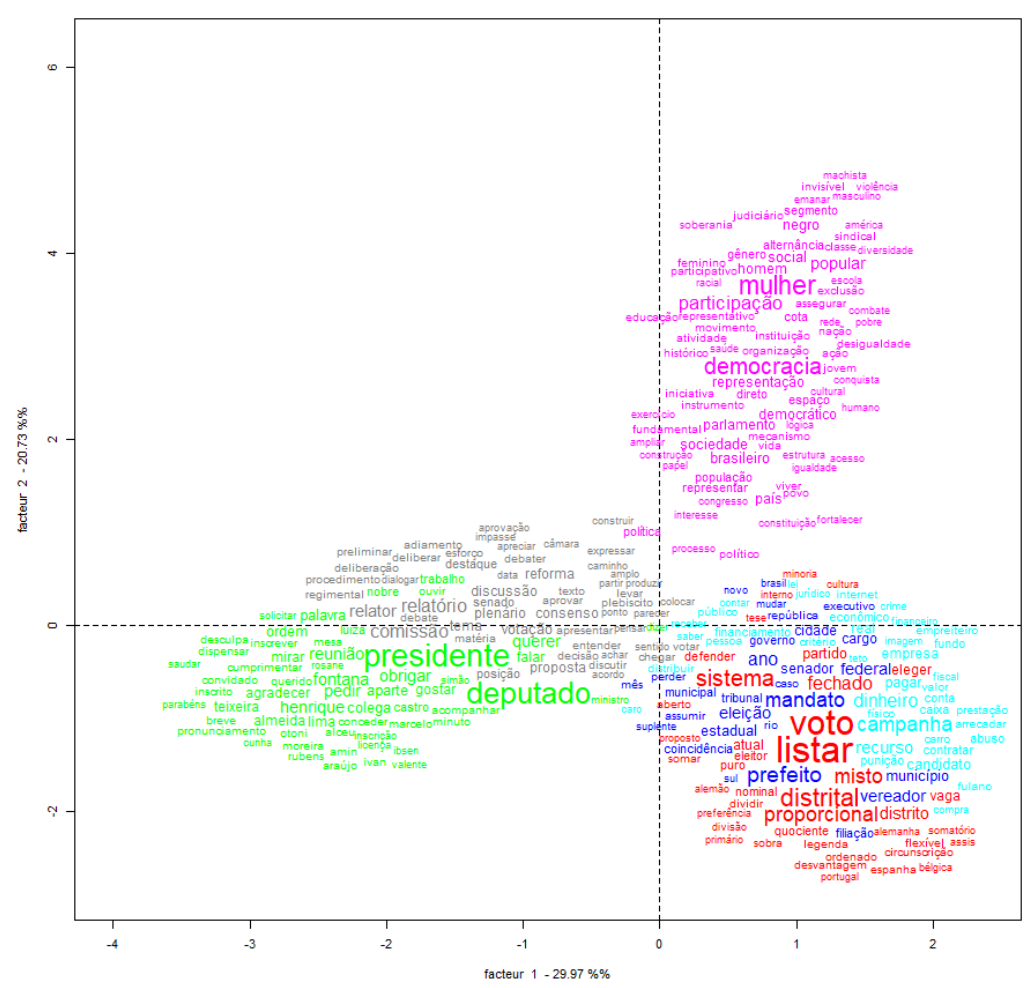




\section{REVISTA ESTUDOS POLÍTICOS}

Vol. 11 | N.22
A CONSTITUIÇÃO DE 1988 E A REFORMA POLÍTICA NO BRASIL:

LIÇÕES DE QUATRO MOMENTOS DE VOTAÇÃO

Eric Nogueira Andrade

Fonte: Elaboração própria

Figura 3 - Discursos agregados por deputados. Comissão de 2015.

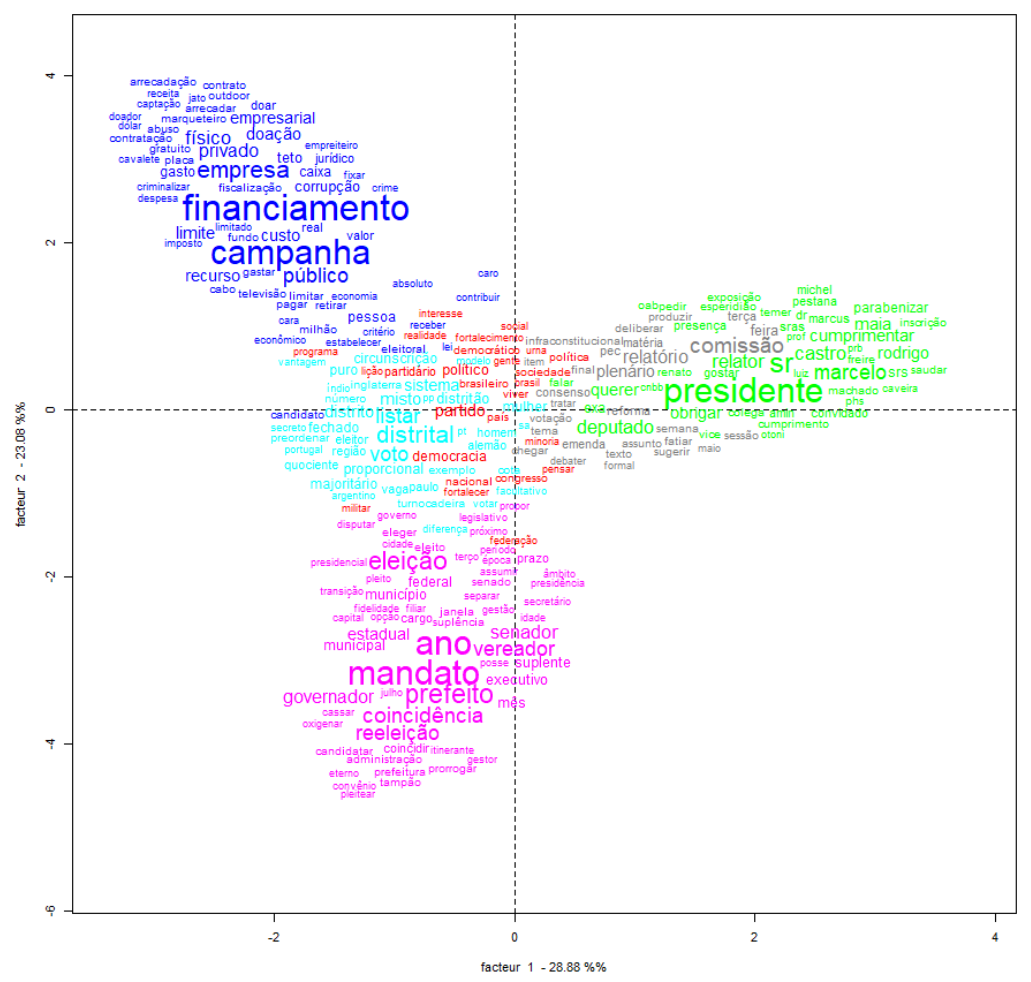

Fonte: Elaboração própria. 
Figura 4 - Discursos agregados por deputados. Comissão de 2016.

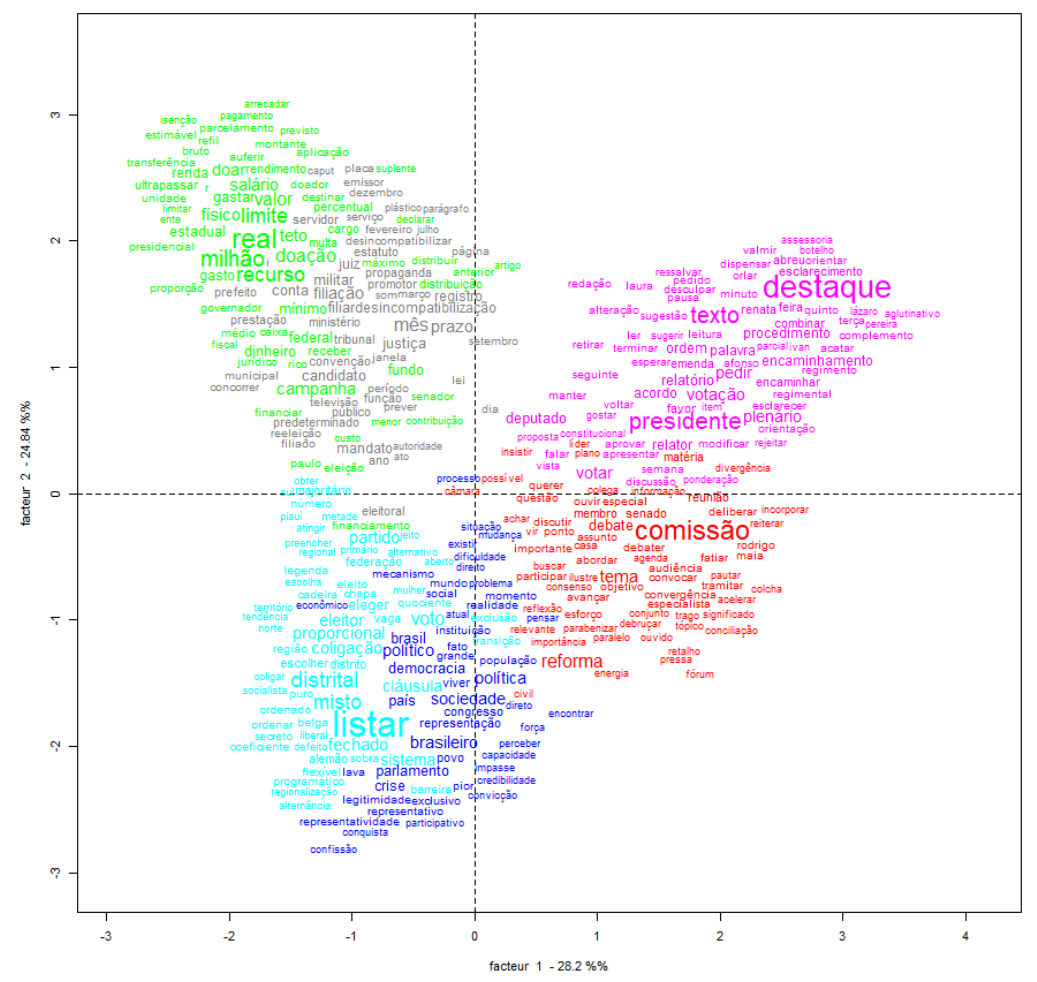

Fonte: Elaboração própria.

Em primeiro lugar, temos em todas as figuras duas classes que se utilizam de vocabulário puramente formal. Palavras como "presidente", "deputado", "relator", "pedir", "palavra" etc. usadas enquanto comunicação elementar entre os deputados de qualquer comissão, são parte da formalidade técnica própria do funcionamento parlamentar. Palavras como "comissão", "tema", "matéria", "plenário", "discutir" etc. representam outra sequência formal necessária nas discussões, e tratam de procedimentos e regras próprios do funcionamento regimental. Estas classes aparecem de forma bastante distinta das demais, formando um polo em separado. Vou chamar essas classes como "formais".

Em oposição ao grupo de palavras "formais" estão as classes com os tópicos mais debatidos na comissão. Quanto mais ao centro, maior é a aproximação entre os discursos, ou seja, mais deputados debateram sobre esses temas. Em três comissões houve um grupo de palavras que abordou sobre o financiamento de campanha. Em 2003 e 2015 representaram uma discussão a parte. Em 2011 estiveram lado a lado das discussões sobre sistemas eleitorais, estando no epicentro da comissão. Mas deixou de ser relevante em 2016, após a decisão judicial de 2015 que tornou inconstitucional o financiamento privado de campanhaiii. A partir de 2011 houve uma classe que abordou exclusivamente sobre sistemas eleitorais. Essa classe é mais presente em 2011, mas também aparece com destaque em 2015 e 2016 e mobiliza palavras típicas de sistemas eleitorais, tais como "lista", "distrital", "distritão", "misto", "voto", "sistema" etc. Além dessas duas classes, houve outras duas que estiveram presente em todas as quatro comissões. A primeira utilizou palavras relativas a regras de candidatura. Essa classe apresentou palavras como "reeleição", "coincidência" das eleições, "suplência", "domicilio" eleitoral e "filiação" partidária, entre muitas outras. Com um enfoque em regras específicas de candidatura. A segunda focou em conceitos democráticos. Esta classe teve um enfoque específico na temática de defesa de minorias, na comissão de 2011, com palavras como "mulher", "negro", "gênero", "cota", dentre outras. Mas também 
repetiu ao longo de todas as comissões palavras como "democracia", "representação", "sociedade", "democrático", "congresso", "país" dentre outras.

Com isso, é possível afirmar que a temática sobre sistemas eleitorais esteve no epicentro dos debates nas comissões de 2011, 2015. Como mostram as figuras 2 e 3. Em 2003 ela teve apenas um papel marginal e em 2016 teve um papel que dividiu relevância com a classe de palavras que tratam de regras específicas de candidatura e campanha, muito provavelmente por causa das discussões sobre a lei da "minirreforma" de 2015 e que sofreu alterações importantes depois dos debates de 2016. Também observamos que a temática do financiamento de campanha foi profundamente relevante até a decisão judicial de 2015. Essas análises concluem que o objetivo das comissões teve nos sistemas eleitorais grande enfoque, mas não deixaram de tratar outras temáticas. Mais importante, contudo, é verificar que somente em 2003, quando as discussões sobre alterar o sistema eleitoral ainda estavam ganhando forma, e em 2016, quando havia um objetivo concreto e "urgente" em debater sobre necessárias alterações na lei da "minirreforma" de 2015, que o tema do sistema eleitoral não foi o centro dos debates. Significa dizer que tanto em 2011 quanto em 2015 as propostas sobre alterar o sistema eleitoral foram intensamente debatidas, e votadas em Plenário ao final da comissão de 2015. Vale destacar que a primeira proposta sobre uma alteração do sistema eleitoral, que veio a ser apreciada em Plenário, foi realizada pela comissão de 2003 e votada em 2007. Este foi o início de sucessivas tentativas de reformar o sistema eleitoral.

\section{As propostas das comissões especiais}

Ao final dos trabalhos, a comissão de 2003 elaborou dois projetos de lei; PL 1712/2003 e PL 2679/2003. O primeiro, votada no dia 25/06/2003, mais ou menos na metade da comissão, tratava apenas de filiação partidária e domicílio eleitoral. A justificativa foi a de conter as migrações partidárias. O segundo projeto de lei foi votado ao final da comissão, no dia 03/12/2003, e foi bem mais ambicioso, sugerindo: cláusula de barreira de 2\%; financiamento exclusivamente público de campanha; proibição de coligações em eleições proporcionais; sistema eleitoral por lista fechada; nova regulamentação sobre pesquisas eleitorais; nova regulamentação sobre propaganda eleitoral; e estabelecendo regras para a criação de federações partidárias. Dos dois projetos de lei, que foram votados apenas na legislação seguinte, em 2007, a PL 1712/2003 foi arquivada após ter sido prejudicada pela rejeição da PL8039/1986 no dia 30 de maio de 2007, e a PL 2679/2003 foi apensada a PL 5268/2001, da comissão especial de reforma política de 2001, e transformada na PL 1210/2007. Durante as votações deste último projeto de lei, foi acordado que a votação deveria ser feita em duas etapas; primeiro seria votado a proposta de lista preordenada e num segundo momento as demais propostas em caso de aprovação da primeira. $\mathrm{O}$ acordo tomou forma de requerimento e foi aprovado em Plenário. Na votação, ocorria na noite do dia 27, o placar final foi de 252 votos contrários e 181 favoráveis. Dessa forma, foi justamente a questão do sistema eleitoral o algoz de todo o processo de reforma da comissão de 2003.

A comissão de 2011 foi, basicamente, na mesma direção que a de 2003, sugerindo propostas muito parecidas para: o sistema eleitoral; o financiamento de campanha; e a criação de federações partidárias. Não houve, no relatório final, a sugestão referente à proibição das coligações nem a sugestão de instituir uma cláusula de desempenho ou de funcionamento parlamentar como da comissão de 2003, mas houve, pela primeira vez, a proposta de emendas constitucionais. Contudo, a falta de acordos em relação ao sistema eleitoral e financiamento exclusivamente público de campanha, fizeram com que o relatório final sequer fosse aprovado, sendo a comissão obstruída. 

VOTAÇÃO

Eric Nogueira Andrade

Foi em 2015 que ocorreu uma importante reviravolta nas propostas referentes ao sistema eleitoral e financiamento de campanha. Pela primeira vez se propunha um sistema da família majoritária ao invés de proporcional, como tem sido a tradição brasileira desde 1934. Desse modo, o sistema majoritário conhecido no Brasil como "distritão", e pela literatura internacional como single non-transferable vote-SNTV (NICOLAU, 2012), esteve no relatório final assim como: uma nova proposta sobre o financiamento de campanha, dessa vez permitindo doações privadas; novamente a proposta de proibir coligações; e novamente a proposta de uma cláusula de desempenho. Além de inúmeras pequenas alterações nas três leis que formam a base da legislação eleitoral no país. Apesar disso, o relatório final não foi votado em plenário, pois na última sessão da comissão, quando votariam o projeto final, a comissão foi dissolvida, causando espanto e insatisfação entre muitos deputados. Como resultado do cancelamento da comissão especial de reforma política, antes mesmo que ela pudesse aprovar o seu relatório final, o presidente da Câmara articulou para que fosse votada, em seu lugar, a PEC 182/2007 em plenário e, posteriormente, também seria votada a PL 5735/2013 (rotulada midiaticamente como "minirreforma política"). Com isso, praticamente todos os pontos discutidos na comissão foram contemplados em Plenárioiv e foram votadas no um a um.

Por fim, a comissão de 2016 retomou a proposta de alterar o sistema eleitoral para o distritão, com a diferença que dessa vez previu-se o uso desse modelo apenas para as duas primeiras eleições e posteriormente o modelo eleitoral do tipo misto. Propostas de proibição das coligações e da criação de uma cláusula de desempenho também foram retomadas e, dessa vez, aprovadas. As alterações nas três leis que compõem a legislação eleitoral foram basicamente na direção de retomar as discussões da comissão anterior em face da decisão judicial de proibir o financiamento privado de campanha.

\section{Dimensão intrapartidária e interpartidária}

Para entendermos as implicações práticas de todo esse longo processo de reformas, sugeri, no início deste artigo, analisarmos as leis alteradas tendo como base duas dimensões de reformas; com efeito interpartidário; e com efeito intrapartidário.

Quadro 2 - Resumo dos principais artigos das leis $n^{\circ}$ 9.096/95, 9.504/97 e 4.737/65, que afetam as dimensões interpartidária e intrapartidária.

\begin{tabular}{|l|l|l|}
\hline Lei dos partidos & Legenda & Reforma \\
\hline Art. 7 e 8 & Requisitos para o registro partidário & Redistributiva \\
Art. 13 & Requisitos para o funcionamento parlamentar* & Redistributiva \\
Art. 41 & Requisitos para a distribuição do fundo partidário & Redistributiva \\
Art. 49 & Requisitos para o acesso gratuito ao rádio e à & Redistributiva \\
& televisão** & \\
\hline Lei das eleições & & \\
\hline Art. 5 & Determina como válidas os votos em candidatos e & Intrapartidária \\
Art.6 & legenda partidárias & Redistributiva \\
Art. 10 & Regula a coligação partidária*** & Intrapartidária
\end{tabular}



VOTAÇÃO

Eric Nogueira Andrade

\begin{tabular}{|c|c|c|}
\hline $\begin{array}{l}\text { Art. } 16 \\
\text { Art. } 47\end{array}$ & $\begin{array}{l}\text { partidos } \\
\text { Requisitos para o acesso ao fundo especial de } \\
\text { Financiamento de campanha (FEFC) } \\
\text { Requisitos para o cesso ao horário gratuito eleitoral }\end{array}$ & Redistributiva \\
\hline \multicolumn{3}{|c|}{ Código eleitoral } \\
\hline Art.104 & $\begin{array}{l}\text { Determina, entre outras coisas, que a cédula eleitoral } \\
\text { deverá conter um nome ou número do candidato } \\
\text { preferido e a sua sigla partidária }\end{array}$ & Intrapartidária \\
\hline Art. 105 & Permite a coligação partidária*** & Redistributiva \\
\hline Art. 108 & $\begin{array}{l}\text { Determina uma cláusula de desempenho para o } \\
\text { candidato }\end{array}$ & Intrapartidária \\
\hline Art.109 & $\begin{array}{l}\text { Calculo da distribuição das cadeiras entre os } \\
\text { candidatos dentro do partido }\end{array}$ & Intrapartidária \\
\hline
\end{tabular}

Fonte: Elaboração própria.

Notas: * conhecida pelo termo "cláusula de desempenho", foi declarada inconstitucional pelo Supremo Tribunal Federal.

$$
\begin{aligned}
& \text { ** propaganda partidária no rádio e TV. Revogada pela lei n 13.487/2017. } \\
& \text { *** proibida pela emenda constitucional } n^{\circ} 97 / 2017 \text {. }
\end{aligned}
$$

O quadro 2 nos mostra os principais artigos das três leis objeto do processo de reforma eleitoral das comissões especiais, em termos de efeitos interpartidário e intrapartidário. Uma vez que as reformas interpartidárias do tipo "eficiente" não alteram o status quo entre as forças políticas, selecionei apenas os artigos do tipo "redistributivos".

Como é possível observar, a lei dos partidos institui alguns requisitos mínimos para a atividade partidária. Se o partido não alcança-los, ficam sem poder se registrar (Art. 7 e 8) ou sem o acesso ao fundo partidário (Art. 41). Em resumo, desde a instituição dessa lei, não houve mudança com relação aos requisitos mínimos, com exceção da declaração de inconstitucionalidade da cláusula de desempenho (Art.13) e da revogação da propaganda partidária no rádio e TV (Art. 49).

A lei das eleições afeta diretamente duas dimensões da análise intrapartidária. Primeiramente, determina que o eleitor pode votar tanto em candidatos quanto em legendas partidárias (Art. 5). Este artigo indica que o eleitor tem a possibilidade de interferir entre os candidatos do seu partido preferido, o que toca na primeira dimensão de análise de reformas intrapartidárias como apresentado pelo quadro 1, mas não diz em quantos candidatos será possível votar. Segundo, determina o número máximo de candidatos permitidos por partidos, até $150 \%$ do número de cadeiras disponíveis no distrito, afetando a sexta dimensão de análise de reformas intrapartidárias ao estipular o grau em que o eleitor pode expressar preferências entre os candidatos. Neste caso, quanto mais candidatos por partido, maior o grau de escolha intrapartidária. Outras duas regras do tipo redistributiva determinam requisitos para o acesso ao fundo especial de financiamento de campanha, criado em 2017, e para o acesso à propaganda eleitoral gratuita. As reformas ocorridas desde então promoveram pequenas alterações nos requisitos para o acesso à propaganda gratuita 

VOTAÇÃO

Eric Nogueira Andrade

eleitoral, reduzindo o tempo de propaganda e aumentando o quesito redistributivo da lei ao reduzir o montante destinado igualitariamente a todos os partidos, uma vez que a maior parte é destinada proporcionalmente ao número de representantes que os partidos possuem. Também foi aprovada a proibição das coligações ${ }^{\vee}$.

Por último, o código eleitoral afeta três dimensões intrapartidárias. Primeiro, determina que a cédula eleitoral conterá apenas um nome ou número do candidato preferido e a sua sigla partidária. Ou seja, o eleitor pode votar em apenas um candidato. Segundo, determina (Art. 108) um limite de $10 \%$ do quociente eleitoral para o exercício de pooling, afetando a $7^{\circ}$ dimensão presente no quadro 1 . Terceiro, determina como o eleitor pode afetar a escolha intrapartidária, "segundo a ordem de votação", conforme o artigo 109. Ou seja, o eleitor tem total domínio da escolha intrapartidária. Além disso, o artigo 105 permite a coligação partidária, mas se tornou inconstitucional desde a EC n 97/2017 que proíbe coligações no âmbito das eleições proporcionais. O processo de reformas brasileiro afetou apenas a $7^{\circ}$ dimensão intrapartidária ao incluir nova redação no artigo 108 do código eleitoral e a proibição das coligações.

Além das alterações nas três principais leis que formam a base da legislação eleitoral no Brasil, as comissões especiais recomendaram algumas mudanças na Constituição. $A$ principal e mais polêmica sugestão foi a proposta de um novo sistema eleitoral. Mas também houve propostas igualmente polemicas como: (1) o fim das coligações em eleições proporcionais; (2) o estabelecimento de financiamento exclusivamente públicos de campanha; e (3) a instituição de uma cláusula de desempenho parlamentar. Tratarei dessas quatro propostas de emendas constitucional em detalhes.

O fim das coligações e do financiamento privado, através da instituição de financiamento exclusivo público, foram ambas sugestões da comissão de 2003 que não chegaram a ser votadas no Plenário e foram apresentadas em formato de projeto de lei. Uma nova proposta para o fim das coligações foi novamente apresentada em 2015, dessa vez como proposta de emenda constitucional, mas foi recusada. Finalmente em 2016 a mesma proposta seria aprovada. A questão do financiamento exclusivamente público de campanha se repetiu nas discussões de 2011, mas novamente não foi para o Plenário devido à obstrução daquela comissão. Uma nova proposta foi apresentada e aprovada, em 2015, mas era radicalmente diferente daquelas apresentadas em 2003 e 2011, e regulava o financiamento privado de campanha. Apesar disso, foi prejudicada por uma decisão judicial que declarou a inconstitucionalidade do financiamento privado de campanha, encerrando o tópico.

A cláusula de desempenho parlamentar, por outro lado, já havia sido instituída pela lei dos partidos de 1995 (Lei n 9.096/1995), com a expectativa que fosse implementada apenas a partir das eleições de 2007. Foi sugerida uma redução da "barreira" de $5 \%$ para $2 \%$, pela comissão de 2003 , mas não chegou a ir ao plenário para votação. Uma decisão judicial em 2007, no entanto, suspendeu o artigo (art.13) que previa essa regra. A decisão foi tomada em dezembro de 2006 e concluídos todos os trâmites legais em 2007, vindo a tempo de impedir o funcionamento da "barreira" para o pleito de 2006. Este veredito foi em resposta a um pedido ajuizado pelo Partido Comunista do Brasil (PCdoB) e pelo Partido Socialista Cristão (PSC), através de dois pedidos de ação direta de inconstitucionalidade $n^{\circ}$ 1351 e $n^{\circ} 1354$, alegando que os dispositivos impugnados violavam o princípio de igualdade de condições entre os partidos políticos, assim como o regime democrático, a pluralidade de partidos e o princípio da proporcionalidade. O dispositivo em questão, da lei de 1995, fixava uma regra para o "funcionamento parlamentar" de partidos políticos, segundo a qual, um partido político só poderia atuar no Congresso e dispor de acesso à propaganda eleitoral gratuita no rádio e na TV e de recursos do Fundo Partidário, se obtivesse no mínimo 5\% dos 
votos - excluindo nulos e brancos - distribuídos em pelo menos um terço dos estados e ao menos $2 \%$ do total dos votos em cada um deles. O termo "funcionamento parlamentar" gerou algumas controvérsias mas, o entendimento dominante foi que não se tratava de uma "barreira" stricto sensu, uma vez que os deputados eleitos por partidos que não atingissem tal regra, não perderiam o mandato (NICOLAU, 2017: 144). Uma nova proposta de instituir a cláusula de desempenho foi apresentada em 2015, dessa vez como proposta de emenda constitucional. Ainda assim, era muito pouco rígida, estipulando que somente terão direito ao fundo partidário os partidos que elegerem ao menos um representante na Câmara ou Senado. Por último, uma nova PEC, com regras parecidas com a proposta de 1995, seria finalmente aprovada em 2016. Pela emenda constitucional aprovada, terão acesso aos recursos do fundo partidário e à propaganda gratuita no rádio e na televisão os partidos que:

I - obtiverem, nas eleições para a Câmara dos Deputados, no mínimo, $\mathbf{1 , 5 \%}$ (um e meio por cento) dos votos válidos, distribuídos em pelo menos um terço das unidades da Federação, com um mínimo de $\mathbf{1 \%}$ (um por cento) dos votos válidos em cada uma delas; ou

II - tiverem elegido pelo menos nove Deputados Federais distribuídos em pelo menos um terço das unidades da Federação. (EC n 97/2017, grifos meus).

Para as eleições de 2026:

I - obtiverem, nas eleições para a Câmara dos Deputados, no mínimo, 2\% (dois por cento) dos votos válidos, distribuídos em pelo menos um terço das unidades da Federação, com um mínimo de 1\% (um por cento) dos votos válidos em cada uma delas; ou

II - tiverem elegido pelo menos onze Deputados Federais distribuídos em pelo menos um terço das unidades da Federação. (EC n 97/2017, grifos meus).

Para as eleições de 2030:

I - obtiverem, nas eleições para a Câmara dos Deputados, no mínimo, $\mathbf{2 , 5 \%}$ (dois e meio por cento) dos votos válidos, distribuídos em pelo menos um terço das unidades da Federação, com um mínimo de 1,5\% (um e meio por cento) dos votos válidos em cada uma delas; ou

II - tiverem elegido pelo menos treze Deputados Federais distribuídos em pelo menos um terço das unidades da Federação. (EC n 97/2017, grifos meus).

Portanto, foram dois tópicos de grande interesse dos deputados nos quais houve interferência do judiciário. A apresentação de uma proposta de emenda constitucional para a proposta de cláusula de desempenho, em 2015 e 2016, foi em razão da declaração de inconstitucionalidade do STF sobre o artigo 13 da lei dos partidos de 1995.

Por fim, ao recomendar a mudança da lista aberta para lista fechada preordenada, tanto a comissão de 2003 quanto a comissão de 2011 incluíram tal proposta nos projetos de leis que elaboraram, sem a necessidade de uma emenda constitucional. Foram as comissões especiais de 2015 e 2016 que tiveram, necessariamente, que propor uma proposta de emenda constitucional para emplacar a sugestão de alterar o sistema eleitoral para o Distritão. Ainda assim, nenhuma das propostas conseguiu a aprovação. 

VOTAÇÃO

Eric Nogueira Andrade

Com isso, é possível chegarmos a importantes conclusões. Primeiro, que apenas uma dimensão intrapartidária foi afetada pelo processo de reforma desde a Constituição de 1988. A reforma de 2015 limitou o exercício de pooling pelo sistema eleitoral de lista aberta. Essa pequena alteração foi capaz de afetar a proporcionalidade das eleições de 2018, cortando do PSL sete (7) cadeiras de São Paulo. Com 1,47 milhão de votos a mais que o PT (Partido dos Trabalhadores) o PSL obteve cinquenta e duas (52) cadeiras em contraste com as cinquenta e seis (56) do rival. O arcabouço conceitual exibido no início deste artigo, ajuda a avaliar quando uma reforma vai no sentido de reforçar o poder do eleitor ou de reduzi-lo. Como salientado por pesquisas recentes, o objetivo é ir além das análises macro e buscar um entendimento mais completo acerca da dinâmica de mudanças em sistemas eleitorais (JACOB; LEYNAAR 2011; LEYNAAR; HAZAN 2011; COLOMER, 2011).

Ao todo, Renwick e Pilet (2016) consideram sete dimensões de análise. O primeiro, o número de preferências, pode ser de três variações; quando o eleitor não pode expressar qualquer preferência; quando o eleitor pode expressar uma preferência; e quando o eleitor pode expressar mais de uma preferência. O segundo, a distinção entre as preferências, é medido através de Três categorias: quando permite que o eleitor expresse duas preferências (apoia/não apoia), três preferências (exemplo: apoia/neutro/não apoiavi), ou mais de três preferências. A terceira, a distribuição das preferências, é codificada como uma variável dicotômica: se permite ou não permite. A quarta, escolha intrapartidária, é medida pelo número máximo de candidatos por partido nos distritos. A quinta, a distância entre representantes e representados, é medida pela magnitude dos distritos. A sexta, o peso das preferências, é medida, num primeiro momento, por três categorias; sistemas em que 0 eleitor tem total domínio sobre a ordem dos candidatos; sistemas em que o partido tem total domínio sobre a ordem dos candidatos; e sistemas em que partidos e eleitores tem pesos diferentes no estabelecimento da ordem entre os candidatos. Sétimo, pooling, é medido por meio de duas perguntas; se existe ou não existe; e a quantos candidatos o pooling pode ser estendido vii. Considerando este arcabouço conceitual, chegamos ao seguinte resultado ao analisar o processo de reforma brasileiro desde 1988:

Tabela 3 - Reformas eleitorais no Brasil: sete dimensões de análise intrapartidária.

\begin{tabular}{lll}
\hline $\begin{array}{l}\text { Dimensões de análise } \\
\text { intrapartidária }\end{array}$ & Estado atual & $\begin{array}{l}\text { Direção das } \\
\text { reformas }\end{array}$ \\
\hline Dimensão 1 & 1 preferência & Inalterado \\
Dimensão 2 & Duas preferências: apoia/ não apoia & Inalterado \\
Dimensão 3 & Não permite & Inalterado \\
Dimensão 4 & Até $150 \%$ do $\mathrm{n}^{\circ}$ de cadeiras disponíveis & Inalterado \\
Dimensão 5 & Magnitude dos distritos & Inalterado \\
Dimensão 6 & Escolha totalmente reservada aos eleitores & Inalterado \\
Dimensão 7 & Existe pooling & Reduziu \\
\hline
\end{tabular}

Fonte: Elaboração própria.

Em relação à dimensão interpartidária, vimos que houve uma série de iniciativas no sentido de: restringir o registro partidário; restringir o acesso ao fundo partidário; restringir o acesso a tempo de TV e rádio; estabelecer um mínimo de desempenho partidário; e instituir o fim das coligações. Por mais que todas essas iniciativas não se revelaram propostas radicais, sem que fossem de forte impacto no sistema partidário, elas apontam para a 
Eric Nogueira Andrade

direção redistributiva das reformas levadas a cabo até então pelo Legislativo brasileiro.

Paralelamente a essas iniciativas houve algumas decisões judiciais, proferidas pela Suprema Corte, que barraram, ou no mínimo limitaram, o caráter redistributivo de algumas reformas aprovadas pelo Legislativo.

Tabela 4 - Alterações mais relevantes na legislação eleitoral e partidária, pós redemocratização até 2017.

\begin{tabular}{|c|c|c|}
\hline Ano & Alterações & Tipo de Reforma \\
\hline 1993 & $\begin{array}{l}\text { Introdução do financiamento de campanha por doações de pessoas } \\
\text { jurídicas }\end{array}$ & Redistributiva \\
\hline 1994 & Mandato presidencial de cinco para quatro anos & Eficiente \\
\hline 1995 & Lei dos Partidos Políticos & Redistributiva \\
\hline 1996 & Introdução da urna eletrônica & Eficiente \\
\hline 1996 & Introdução de cotas para mulheres de $20 \%$ e depois $30 \%$ viii & Eficiente \\
\hline 1997 & Introdução da reeleição para cargos do executivo & Eficiente \\
\hline 1997 & $\begin{array}{l}\text { Votos brancos e nulos deixam de ser contabilizados no cálculo do } \\
\text { quociente eleitoral }\end{array}$ & Eficiente \\
\hline 1997 & Lei definitiva das eleições & Redistributiva \\
\hline 2002 & Regra da verticalização & Decisão Judicial \\
\hline 2006 & Suspensão da regra da verticalização & Eficiente \\
\hline 2007 & $\begin{array}{l}\text { Suspenção da cláusula de desempenho instituída pela lei dos } \\
\text { partidos }\end{array}$ & Decisão Judicial \\
\hline 2007 & Proibição de troca de legenda & Decisão Judicial \\
\hline 2010 & Lei da ficha limpa & Eficiente \\
\hline 2015 & Lei da Janela partidária & Eficiente \\
\hline 2015 & Lei da "minireforma" & Redistributiva \\
\hline 2015 & $\begin{array}{l}\text { Proibição do financiamento de campanhas por doações de pessoas } \\
\text { jurídicas }\end{array}$ & Decisão Judicial \\
\hline 2017 & Segunda Lei da "minireforma" & Redistributiva \\
\hline 2017 & $\begin{array}{l}\text { Proibição de Coligações nas eleições proporcionais e criação da } \\
\text { cláusula de desempenho partidário }\end{array}$ & Redistributiva \\
\hline
\end{tabular}

Fonte: Elaboração própria.

A tabela 4 nos dá uma visão global acerca das inúmeras reformas na legislação eleitoral que ocorreram desde a Constituição de 1988. Também é possível examinar o tipo de reforma, levando em consideração a tipologia descrita no início deste artigo e que considera que múltiplos atores podem conduzir reformas eleitorais. Por essa tabela podemos identificar seis momentos em que houve reforma "redistributiva", oito reformas "eficientes" e quatro "decisões judiciais".

\section{O sistema eleitoral}


Como vimos, todas as quatro comissões especiais analisadas neste artigo propuseram alterar o sistema eleitoral. Além disso, as discussões na constituinte também votaram por um novo sistema eleitoral que representaria uma mudança em relação ao sistema que foi usado antes do regime militar. Foram, portanto, cinco tentativas de reformar o sistema eleitoral e quatro momentos de votação, uma vez que a comissão de 2011 foi obstruída. Assim como os itens referentes ao fim das coligações e a criação de uma cláusula de desempenho foram constantemente retomadas, até serem aprovadas em 2016, as propostas de reformar o sistema eleitoral são uma constante na Câmara dos Deputadosix. Apesar das tentativas, nenhuma das comissões conseguiu emplacar uma proposta que conseguisse mais de $50 \%$ dos votos em plenário.

Tabela 5 - Propostas de alterar o sistema eleitoral e a porcentagem dos votos.

\begin{tabular}{llrrrr}
\hline Ano & Modelos & \%Contra & \%A favor & \%ABS. & \multicolumn{2}{c}{ Total de votos } \\
\hline 1988 Misto & 69,0 & 28,8 & 2,2 & 493 \\
2007 Lista fechada & 57,4 & 41,6 & 0,9 & 437 \\
2015 & Misto & 78,5 & 21,1 & 0,4 & 470 \\
2015 & Lista fechada & 94,6 & 4,9 & 0,5 & 425 \\
2015 & Distritão & 55,4 & 43,6 & 1,0 & 482 \\
2017 & Distritão e Misto & 53,6 & 42,2 & 0,2 & 444 \\
\hline
\end{tabular}

Fonte: Elaboração própria, com dados da Câmara dos Deputados.

A primeira tentativa real de substituir o sistema eleitoral se deu durante as votações na constituinte, quando uma proposta de adotar o modelo misto de inspiração alemã foi negada. Naquele período, o grosso das críticas sobre o sistema político brasileiro recaíam sobre a junção do presidencialismo com multipartidarismo e propunham a adoção do parlamentarismo. Tanto os políticos profissionais quanto parte dos acadêmicos se empenharam no argumento de que o país deveria alterar o sistema de governo. Esse esforço culminou com o plesbicito de 1993 e a vitória do presidencialismo pelo voto popular. Conforme o governo FHC (1995-2003) e mais tarde Lula (2003-2011) estabilizaram o sistema político, a crítica sobre a suposta ingovernabilidade inerente foi temporariamente suspensa. Mesmo depois da comissão de 2003, que concluiu os trabalhos com um préprojeto sugerindo a alteração do sistema eleitoral, só houve votação em Plenário em 2007, na esteira da crise provocada pelo "escândalo dos sanguessugas", de 2006, e também do mensalão que estourou em 2005. Em 2015, os deputados votaram uma vez mais diferentes propostas para alterar o sistema eleitoral. Dessa vez, logo depois das massivas manifestações anticorrupção de 2013 e mais uma vez influenciadas por um enorme escândalo de corrupção, denunciado pela operação Lava-Jato. As votações retornaram em 2017 depois da queda da presidenta Dilma, em 2016. Ou seja, o sistema eleitoral só foi posto em votação em momentos de elevada insatisfação popular para com a política.

No esforço por compreender o teor das votações em relação às propostas de alterar o sistema eleitoral, alguns autores chamaram a atenção para o fato de que alguns partidos mantiveram forte coesão partidária e experimentaram alianças inusitadas enquanto outros vivenciaram um verdadeiro racha interno. As votações demonstram que não houve as clássicas posições a partir do eixo direita/esquerda ou governo/oposição. (FLEISCHER, 2014; NICOLAU, 2017). Apresento a seguir uma serie de figuras com o percentual de votos, por 
partido, entre as votações favoráveis e contrárias. Devido a excessiva fragmentação partidária, os gráficos ajudam a visualizar a correlação de forças.

Figura 5 - Peso relativo dos partidos favoráveis em 1988.

\section{Votações favoráveis ao modelo misto em 1988 \\ Percentual dos votos por partidos $\quad$ Média}

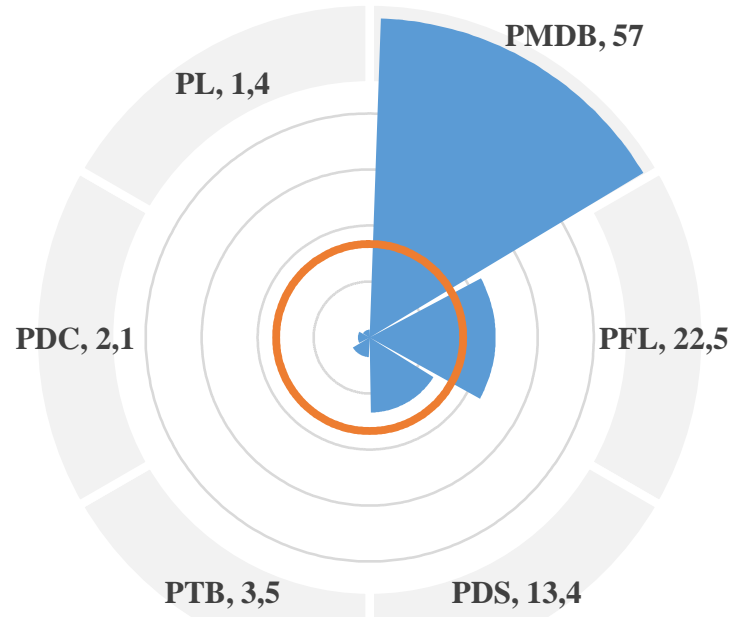

Fonte: Elaboração própria. Diário da Assembleia Nacional Constituinte, ano 2, n. 206, 16 mar. 1988, pp. 8477.

Figura 6 - Peso relativo dos partidos contrários em 1988. 
Eric Nogueira Andrade

\section{Votações contrárias ao modelo misto em 1988 \\ Percentual dos votos por partidos $\quad$ Média}

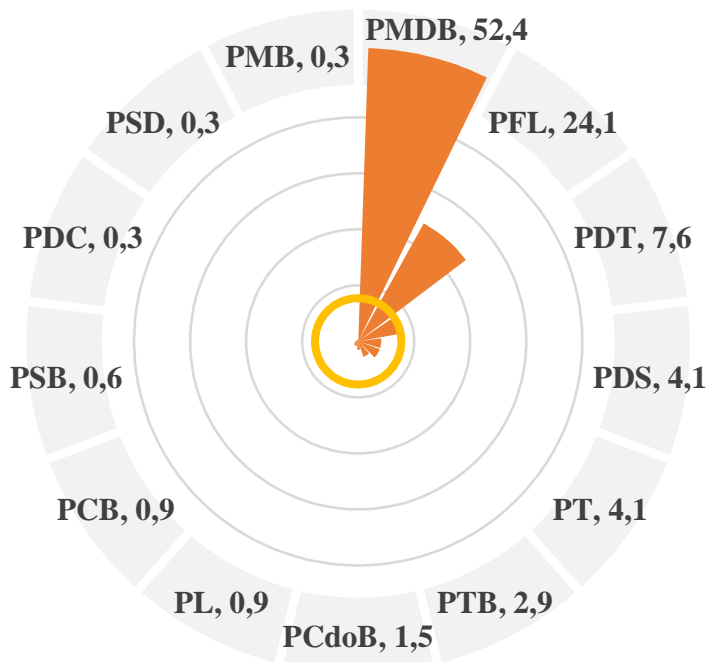

Fonte: Elaboração própria. Diário da Assembleia Nacional Constituinte, ano 2, n. 206, 16 mar. 1988, pp. 8477.

As figuras 5 e 6 nos dão uma visão global sobre a participação dos partidos no apoio ou recusa da proposta do modelo misto durante a constituinte de 1988. Como é possível observar, PMDB, PFL e PDS lideraram as votações favoráveis, contudo, os mesmos partidos, com a adição do PDT, também lideraram os votos contrários. Isso mostra que não houve um posicionamento partidário claro. O que houve, foi uma importante divisão dentro dos maiores partidos, especialmente PMDB, PFL e PDS. Quando o modelo misto foi posto novamente em votação, em 2015, essa relação partidária se alteraria radicalmente. Consideremos, como forma de ilustrar essa afirmação, a figura 7, em que observamos a importância massiva do PSDB nas votações sobre a proposta do modelo misto em 2015.

Figura 7 - Peso relativo dos partidos favoráveis à Emenda Aglutinada n² 2, em 2015. 

VOTAÇÃO

Eric Nogueira Andrade

\section{Votações favoráveis ao modelo misto em 2015 \\ Percentual dos votos por partidos —Média}

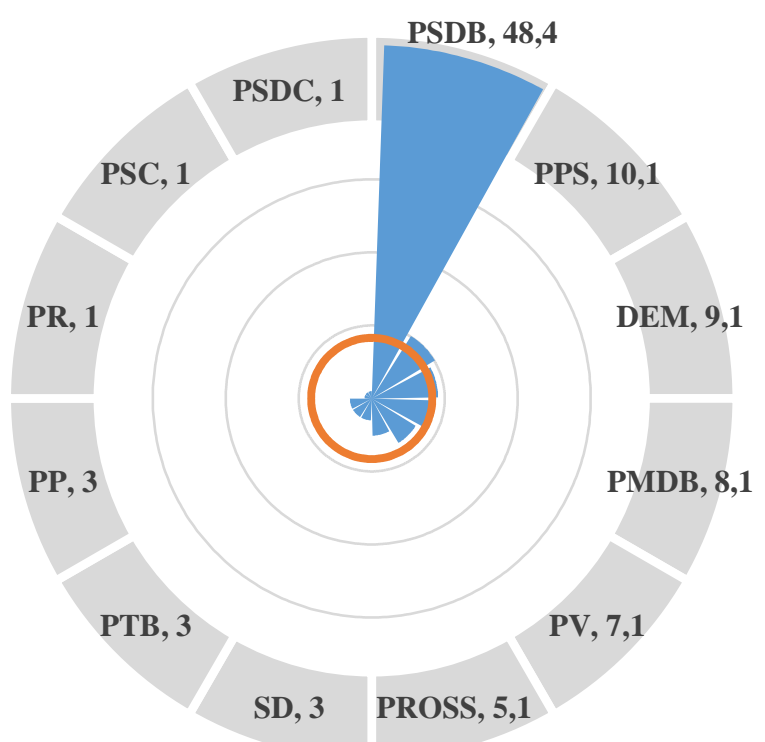

Fonte: Elaboração própria, com dados da Câmara dos Deputados.

A figura 7 nos informa que metade das votações no modelo misto, em 2015, foram do PSDB. O DEM, antigo PFL, se dividiu. Demais partidos tiveram uma contribuição muito pequena. O total dos votos favoráveis foi percentualmente ainda menor que em 1988. Nos votos contrários, uma larga coalizão se formou. Ao todo, membros de vinte sete (27) partidos formaram o bloco que negou tal proposta. Ainda assim, é notável o peso dos votos do PT e do PMDB em comparação com os demais, como mostra a figura 8.

Figura 8 - Peso relativo dos partidos contrários à Emenda Aglutinada n² 2, em 2015. 


\section{Votações contrárias ao modelo misto em 2015}

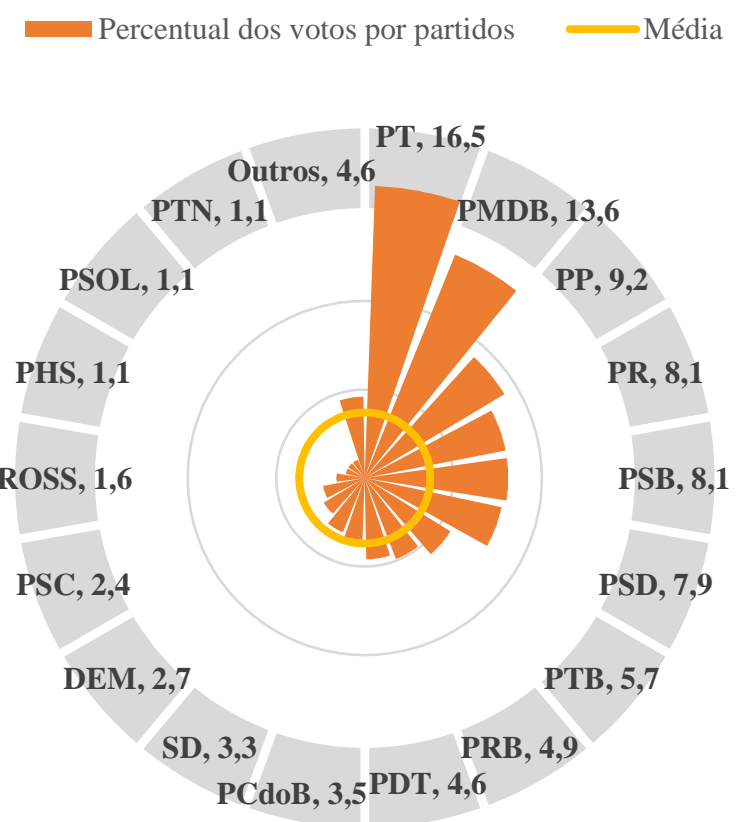

Fonte: Elaboração própria, com dados da Câmara dos Deputados.

Se é verdade que a opção do modelo misto, em 2015, tornou-se uma bandeira, principalmente, do PSDB, a proposta da lista fechada, votada em 2007, tornou-se uma bandeira, especialmente, do PT com o DEM, como nos mostram abaixo as figuras 9 e 10. Naquela ocasião, foi o PMDB junto com o PSDB que lideraram a oposição à proposta da lista fechada. Papel muito semelhante ao desempenhado pelo PT com o PMDB em relação à rejeição do modelo misto, em 2015. No entanto, quando a lista fechada foi novamente posta em votação em 2015 , nenhum partido de peso apoiou a proposta e o resultado foi pífio, com apenas 21 votos favoráveis ${ }^{\times}$. O que chama a atenção, no entanto, é a divisão entre os maiores partidos.

Figura 9 - Peso relativo dos partidos favoráveis em 2007. 
Votações favoráveis ao modelo proporcional por lista fechada em 2007

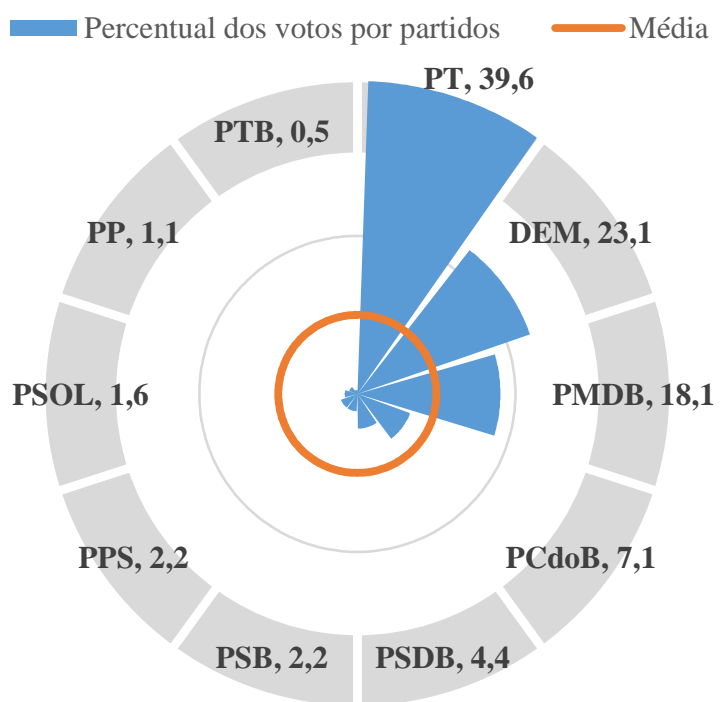

Fonte: Elaboração própria, com dados da Câmara dos Deputados.

Figura 10 - Peso relativo dos partidos contrários em 2007.

Votações contrárias ao modelo proporcional por lista fechada em 2007

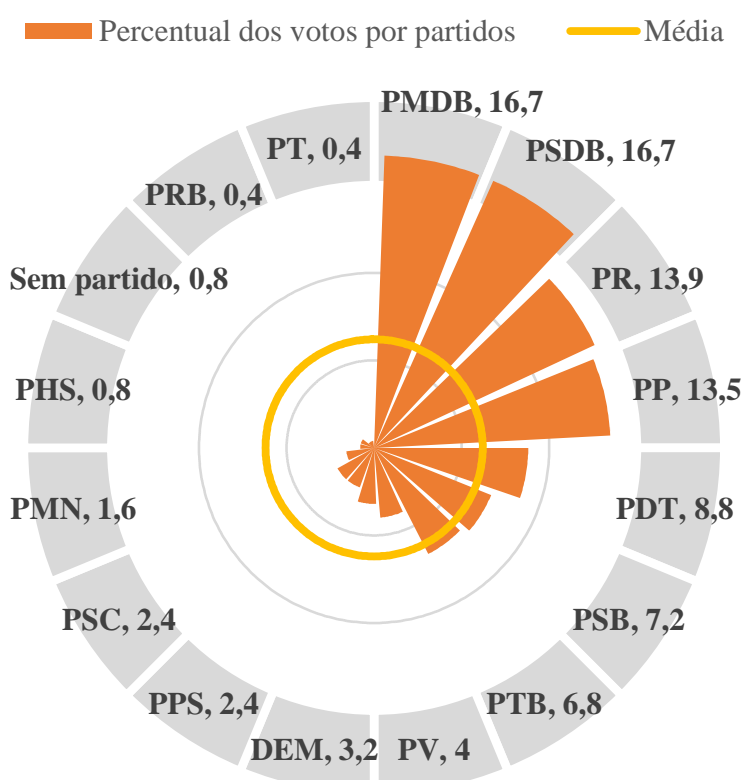


Fonte: Elaboração própria, com dados da Câmara dos Deputados.

A estratégia em 2015 foi colocar várias propostas de sistema eleitoral em votação no Plenário. A alternativa que recebeu mais votos favoráveis foi a proposta do Distritão. Mas novamente o que observamos é uma clara falta de consenso, como nos mostra as figuras abaixo 11 e 12. De um lado estiveram, principalmente, PMDB, PP, PTB, DEM, PCdoB e SD. Do outro PT, PR, PSB, PRB e PDT. PSD e PSDB se dividiram. O partido que fez ferrenha oposição a tal proposta foi o PT. Depois da derrota, houve semelhante esforço em 2017. Dessa vez, uma única proposta determinava o Distritão para as primeiras duas eleições e o modelo misto posteriormente. É possível que essa sugestão tivesse como base uma aliança entre PMDB e PSDB, uma vez que ambos os partidos se aproximaram depois de um processo dúbio de impeachment, em 2016, que deu a presidência ao PMDB. Do ponto de vista teórico, não existe nenhuma conexão entre esses dois modelos eleitorais que justifique tal proposta. 0 primeiro, de matriz majoritária. O segundo, em referência ao exemplo alemão, busca resultados proporcionais. Naturalmente que o PT continuou como o principal opositor de tal projeto.

Em 2017, vemos uma maior disciplina partidária dentro do PMDB que junto com o PP, DEM e SD continuaram apoiando a proposta de reforma. PSD e PODEMOS agregaram forças. O PSDB continuou dividido, embora tenha aumentado a parcela dos apoiadores, e o PTB diminuiu bancada e se dividiu. O número total de partidos com deputados apoiando a proposta caiu de 21 para 16. Do outro lado, PT, PR, PSB, PRB e PDT, continuaram opositores. PCdoB agregou forças. O número total de partidos rejeitando a proposta aumentou de 23 para 24. Assim, o resultado final, mesmo com a inclusão do modelo misto, não afetou muito o peso da correlação de votos favoráveis vis-à-vis contrários. A partir das figuras abaixo, podemos observar as semelhanças e diferenças entre as votações.

Figura 11 - Peso relativo dos partidos favoráveis ao Art. $1^{\circ}$ do Substituto do Relator em 2015.

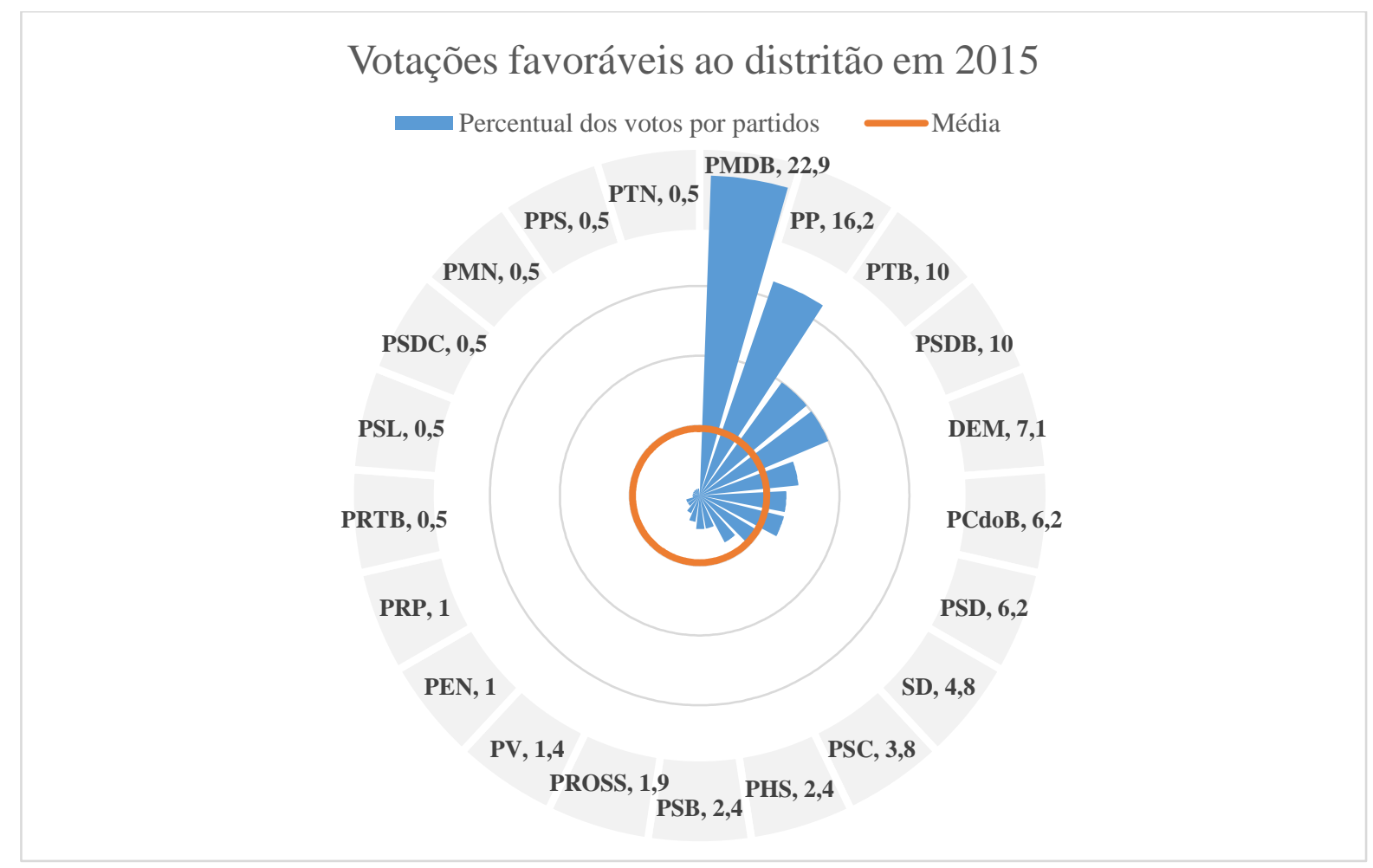

Fonte: Elaboração própria, com dados da Câmara dos Deputados. 
Eric Nogueira Andrade

Figura 12 - Peso relativo dos partidos contrários ao Art. $1^{\circ}$ do Substituto do Relator em 2015.

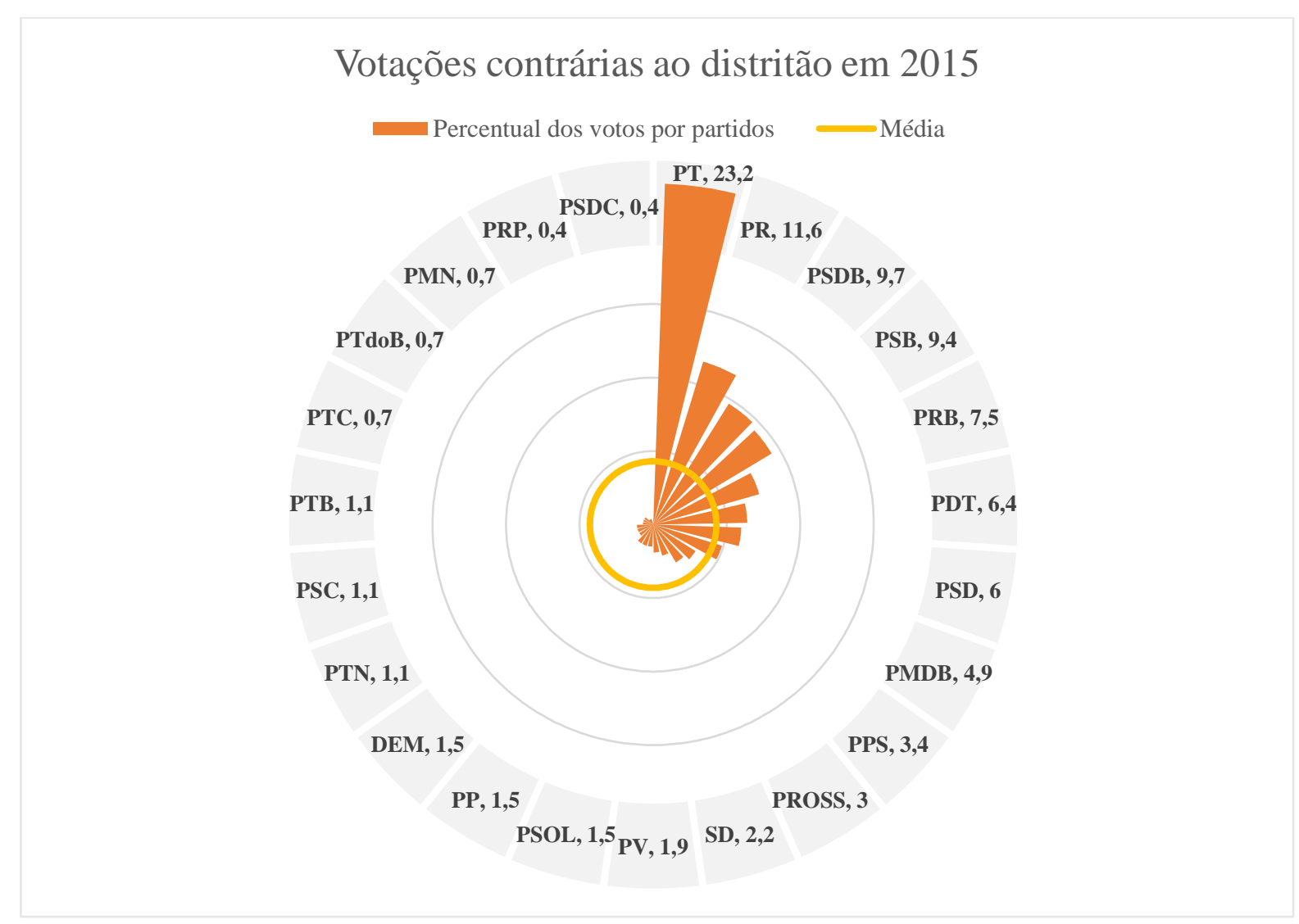

Fonte: Elaboração própria, com dados da Câmara dos Deputados.

Figura 13 - Peso relativo dos partidos favoráveis em 2017. 


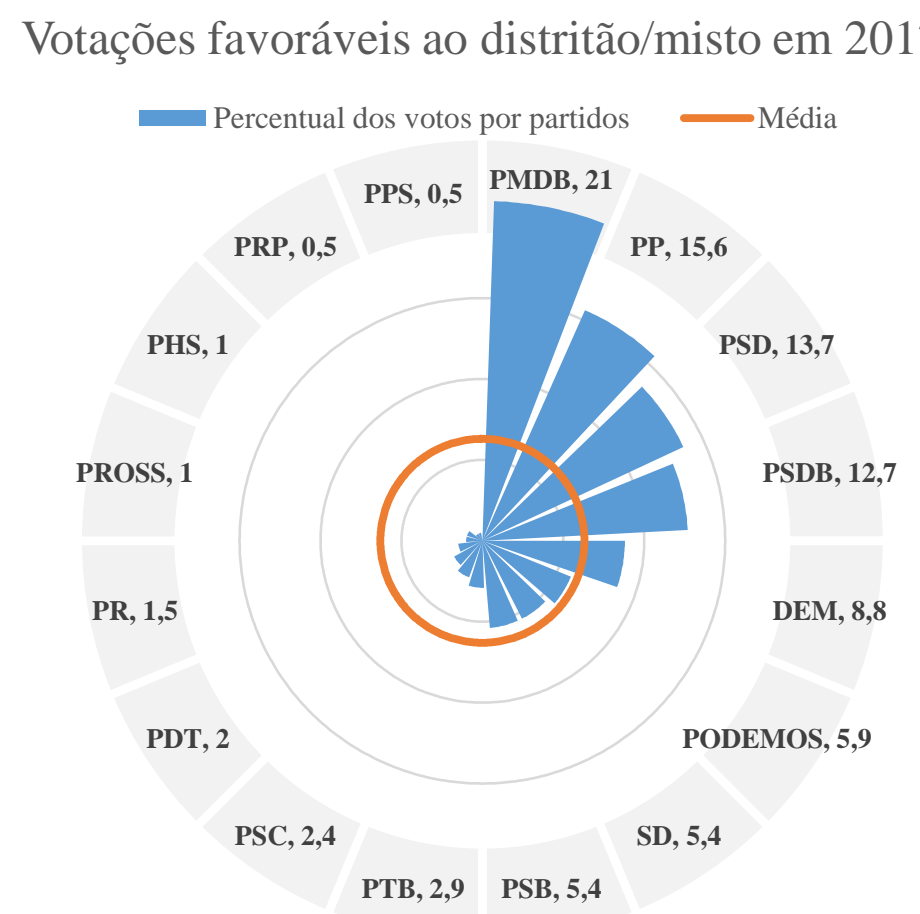

Fonte: Elaboração própria, com dados da Câmara dos Deputados.

Figura 14 - Peso relativo dos partidos contrários em 2017.

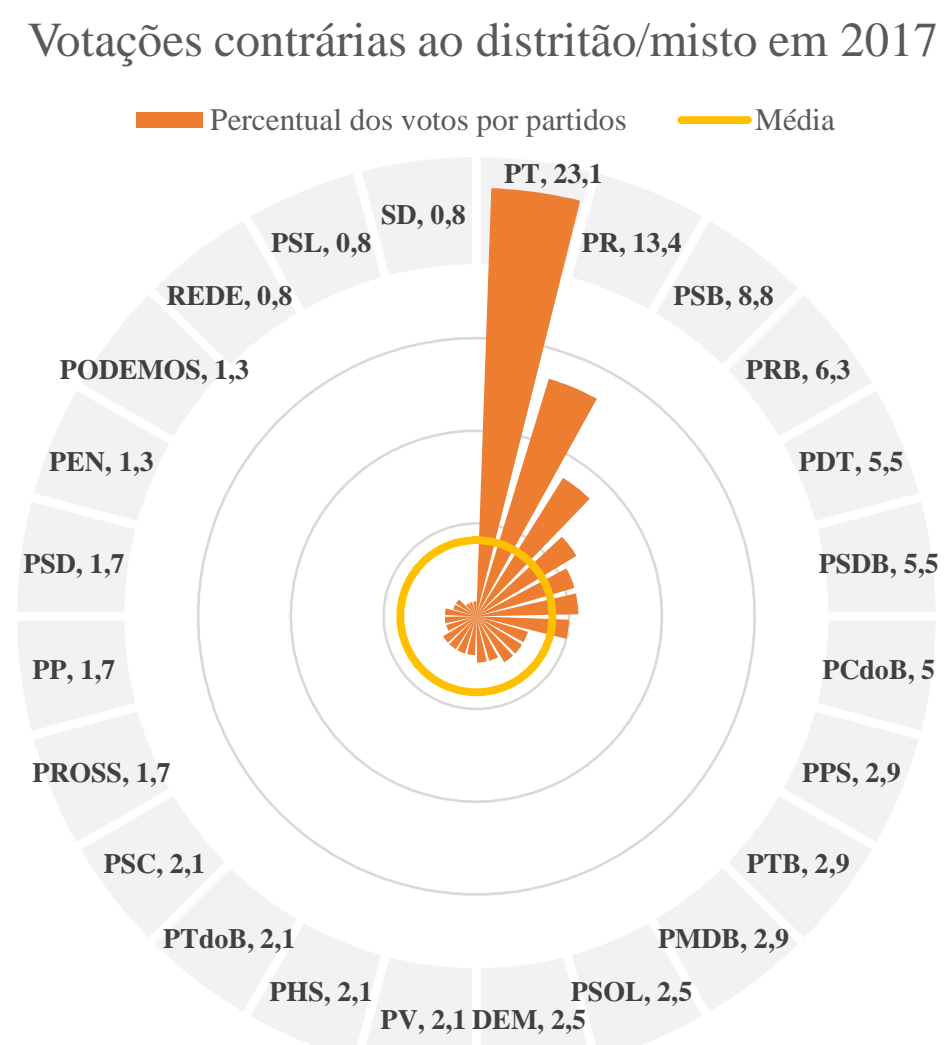


Fonte: Elaboração própria, com dados da Câmara dos Deputados.

\section{Considerações finais}

Taagepera e Shugart (1989: 218-236) assinalam que "o mais importante propósito das eleições é promover um quadro institucional estável para a expressão dos diversos pontos de vista". E que um sistema eleitoral estabelecido ao longo do tempo, ainda que imperfeito, pode satisfazer este propósito melhor que um modelo novo e não familiarizado, ainda que este último seja, aparentemente, mais vantajoso. As razões para isso, segundo Taagepera e Shugart, são que as forças políticas que se encontram em desvantagens sob as regras existentes aprendem a conviver com elas construindo estratégias que minimizam os prejuízos.

Vimos que os discursos dos deputados dentro das comissões tiveram no sistema eleitoral um grande enfoque, especialmente a partir da comissão de 2011. Mas também houve enfoque em relação ao financiamento de campanha, regras de candidatura e conceitos democráticos mais amplos. As análises sugerem que as instituições brasileiras foram profundamente debatidas. As propostas provenientes das comissões não deixam dúvidas sobre a direção das tentativas de aprimoramento institucional. Reformas redistributivas buscaram aumentar os limites sobre a entrada e funcionamento parlamentar dos partidos, por meio de requisitos sobre: o registro, o acesso ao fundo de campanha e o acesso ao tempo de rádio e TV. Além de instituírem a cláusula de desempenho e a proibição de coligações. Paralelamente, houve a redução do poder de escolha do eleitor ao limitar o efeito pooling do sistema eleitoral. Por fim, propostas de alterar o sistema eleitoral apontam para tentativas distintas de efeito redistributivo e de efeitos intrapartidários que não são tão claros como se possa imaginar. Por exemplo, houve propostas de reduzir o poder de escolha do eleitor com a lista fechada, assim como de aumenta-lo com a proposta de distritão. Mas também houve propostas com o misto de ambos, como o distrital misto que dependeria também, para uma maior clareza de qual direção apontaria, da definição de outras regras. Nenhuma, contudo, logrou o apoio necessário.

Portanto, não é possível afirmar que a Câmara dos Deputados perseguiu um projeto de reforma único e acabado. Existem diferentes tópicos que foram pontualmente colocados em debate, mas que de fato avançaram ao longo dessas quase duas décadas de debates. As propostas de instituir uma cláusula de barreira e do fim das coligações são bons exemplos. Ao mesmo tempo, houve constante interferência do judiciário, o que provocou reações precisas do Legislativo, e um plesbicito popular. Essas interferências demonstram o compartilhamento do processo de reforma, e não o domínio por parte dos políticos profissionais.

(Recebido para publicação em agosto de 2020)

(Reapresentado em setembro de 2020)

(Aprovado para publicação em dezembro de 2020)

\section{Cite este artigo}

ANDRADE, Eric, 2020. A Constituição de 1988 e a reforma política no Brasil: Lições de quatro momentos de votação. Revista Estudos Políticos: a publicação semestral do 
Eric Nogueira Andrade

Laboratório de Estudos Hum(e)anos (UFF). Rio de Janeiro, Vol.11 | N.22, pp. 189-223, dezembro de 2020.

\section{NOTAS}

1. Não incluí na analise a presente comissão especial, instalada em 2021, por estar em pleno andamento.

2. Com a exceção da comissão de 2015 , todas as demais funcionaram por volta de um ano. A comissão de 2003 teve 26 sessões e 199.824 palavras em 9 meses. Em 2011 foram 42 sessões com 483.488 palavras em 14 meses. Em 2015 foram 25 sessões, 341.607 palavras e 4 meses de discussão. E 2016 teve 26 sessões, 347.020 palavras e 11 meses de funcionamento.

3. Até a decisão judicial que tornou o financiamento por empresas inconstitucional, havia um grande embate entre deputados contrários e aqueles favoráveis à participação privada quase irrestrita nas campanhas.

4. No caso do sistema eleitoral, não só o distritão foi votado mas também o modelo misto e a lista fechada.

5. Antes da proibição das coligações, a reforma de 2015 instituiu uma pequena mudança no artigo 10 sobre o número de candidatos permitidos por partidos. A nova redação acrescentou que as coligações contariam como se fossem um único partido no limite das candidaturas. Essa regra, no entanto, tornou-se obsoleta com a proibição das coligações em 2017.

6. Na Suíça e em Luxemburgo é permitido ao eleitor expressar: no votes, one vote, two votes.

7. Na maioria dos casos um aumento na magnitude dos distritos eleva o grau de pooling. À exceção de sistemas proporcionais por lista fechada. Nesses casos, um aumento na magnitude, reduz o grau de personalização.

8. O termo "cota para as mulheres" foi retirado do site oficial da Câmara dos Deputados, quando trataram da PEC 182/2007. A lei $n^{\circ} 9.100 / 95$ especifica que "Vinte por cento, no mínimo, das vagas de cada partido ou coligação deverão ser preenchidas por candidaturas de mulheres". Em 1997 a cota foi ampliada para trinta por cento, pela Lei 9.504, e houve a substituição de "mulheres" por "cada sexo" para designar a cota. Este autor não pretende abordar conceitualmente este tema, limitando-se a utilizar o termo presente no site da Câmara, muito embora reconheça a complexidade do assunto.

9. A comissão especial de reforma política (PEC 125/11) instalada enquanto este artigo estava sendo desenvolvido, 
Eric Nogueira Andrade

também contém a ambição de propor uma reforma de sistema eleitoral.

10. O PT se justificou dizendo que se negou a votar em protesto à condução relâmpago do processo de votação, estabelecido pelo presidente da Câmara.

\section{Referências Bibliográficas}

ALTMAN, David. "Plebiscitos, referendos e iniciativas populares en América Latina: ¿mecanismos de control político o políticamente controlados?" México. Perfiles Latinoamericanos, 2010, vol. 35, pp. 9-34.

ANDRADE, Eric N. Reforma Política e Sistema Eleitoral no Brasil: uma análise comparativa com a experiência alemã. Rio de Janeiro: Tese de doutorado em Ciência Política. Instituto de Estudos Sociais e Políticos - Universidade do Estado do Rio de Janeiro. 2019

ABRANCHES, Sérgio. Presidencialismo de coalizão: o dilema institucional brasileiro. Dados, 1988 , vol. 31 , no. 1, pp. 538,

AMES, Barry. The Deadlock of Democracy in Brazil: Interests, Identities, and Institutions in Comparative Politics. Ann Arbor: University of Michigan Press. 2001.

Janeiro: FGV, 2003.

AMORIM NETO, Octavio. "A reforma do sistema de governo: rumo ao parlamentarismo ou ao semipresidencialismo". In: SOARES, Gláucio Ary; RENNÓ, Lúcio. (orgs.). Reforma política: lições da história recente. Rio de Janeiro: Fundação Getúlio Vargas. 2006.

BEHNKE, Joachin; GROTZ, Florian; HARTMANN, Christof. Wahlen und wahlsysteme. Oldenbourg: De gruyter. 2017

BENOIT, Kenneth., "Models of electoral system change". Electoral studies, 2004, vol. 23, pp. 363-389.

"Electoral laws as political consequences: Explaining the origins and change of electoral institutions". Annual review of Political Science, 2007, vol. 10, pp. 363390.

BOIX, Charles. "Setting the rules of the game: The choice of electoral systems in advanced democracies". American Political Science review, 1999, vol. 93, pp. 609-624.

BOWLER, Shaun; DONOVAN, Todd; KARP, Jeff. "Why politicians like electoral institutions: Self-interest, values, or ideology?" Journal of politics, 2006, vol. 68, no. 2, pp. 434446. 
BOWLER, Shaun; DONOVAN, Todd. "Election reform and (the lack of) electoral system change in the USA". In: BLAIS, André (ed.). To keep or to Change First Past the Post? The Politics of Electoral Reform. Oxford: Oxford University Press, 2008, pp. 90-111.

CAREY, John M.; SHUGART, Matthew S., "Incentives to cultivate a personal vote: A rank ordering of electoral formulas". Electoral studies, 1995, vol. 14, no. 4, pp. 417439.

COLOMER, Josep M., "The strategy and history of electoral system choice". In: COLOMER, Josep M. (ed.). Handbook of electoral system choice. Basingstoke: Palgrave Macmillan, 2004, pp. 3-78.

. Personal representation: The neglected dimension of electoral systems. Colchester: ECPR Press, 2011.

COX, Gary W. Making votes count: Strategic coordination in the world's electoral systems. Cambridge: Cambridge University Press, 1997.

CÂMARA DOS DEPUTADOS. Anais da Câmara dos Deputados disponível em: https://www2.camara.leg.br

CINTRA, Antonio Octávio. "Majoritário ou proporcional? em busca do equilíbrio na construção de um sistema eleitoral". In: FLEISCHER, David; ABRANCHES, Sérgio; CINTRA, Antônio; RIAL, Juan; SPECK, Bruno (orgs.). Reforma política: Agora vai? Rio de Janeiro: Konrad Adenauer, 2005.

"A origem é o sistema eleitoral". In: CINTRA, Antônio; NOLETO, Pedro; SEABRA, Roberto (eds.). Reforma política. Brasília: Revista plenarium, 2007.

"Reforma política: Mudando os termos da "conexão eleitoral". In: MULHOLLAND, Timothy; RENNÓ, Lúcio L (orgs.). Reforma política em questão. Brasília: UnB, 2008.

DONOVAN, Mark. "The politics of electoral reform in Italy". International political Science review, 1995, vol. 16, pp. 4764.

FIGUEIREDO, Argelina; LIMONGI, Fernando. Executivo e Legislativo na Nova Ordem Constitucional. Rio de Janeiro: FGV, 1999.

FLEISCHER, David. "Análise Política das perspectivas da Reforma Política no Brasil, 2005-2006". In: FLEISCHER, David; ABRANCHES, Sérgio; CINTRA, Antônio; RIAL, Juan; SPECK, Bruno. (Orgs.). Reforma Política: Agora vai? Rio de Janeiro: Konrad Adenauer, 2005.

. "Reforma política em Brasil: uma historia sin fi". Salamanca: América Latina Hoy, 2004, v.ol.37, pp. 81-99. 
. "A Reforma Política no Brasil: uma história sem fim (1995-2011)". In: SOARES, G. A. D; LAVAREDA, Antonio. (orgs.). A Relevância da Ciência Política. Rio de Janeiro: Editora Revan, 2014, pp. 121-147.

JACOBS, Kristof; LEYENAAR, Monique. "A conceptual framework for major, minor, and technical electoral reform". West European politics, 2011, vol. 34, no. 3, pp. 495-513.

KATZ, Richard S. "Why are there so many (or so few) electoral reforms?" In: GALLAGHER, Michael; MITCHELL, Paul (eds.) The politics of electoral systems. Oxford, University Press, 2005, pp. 57-78.

LAMOUNIER, Bolívar. "Brasil: rumo ao parlamentarismo?" In: LAMOUNIER, B. (org.). A Opção Parlamentarista. São Paulo: Sumaré,1991.

. "O modelo institucional dos anos 30 e a presente crise brasileira". Estudos Avançados, 1992, vol. 6, no. 14, pp. 39-57.

. "Brazil: Toward Parlamentarism?" In: J. J. Linz e A. Valenzuela (comps.), The Failure of Presidential Democracy: The Case of Latin America. Baltimore: The Johns Hopkins University Press. 1994.

LEYENAAR, Monique; HAZAN, Reuven Y. "Reconceptualising electoral reform". West European Politics, 2011, vol. 34, no. 3, pp. 437-455.

LIJPHART, Arend. Electoral systems and party systems: A study of twenty-seven democracies, 1945-1990. Oxford: Oxford University Press, 1994.

MACIEL, Débora Alves; KOERNER, Andrei. "Sentidos da judicialização da política: Duas análises". São Paulo: Lua Nova, 2002, no 57, pp. 113-133.

MAINWARING, Scott. "Politicians, Parties, and Electoral Systems: Brazil in Comparative Perspective". Comparative Politics, 1991, vol. 24, no. 1.

"Multipartism, Robust Federalism and Presidentialism in Brazil". In: MAINWARING, S.; SHUGART, M. S (eds.) Presidentialism and Democracy in Latin America. Cambridge: Cambridge University Press, 1997.

NICOLAU, Jairo. Sistema Eleitorais. Rio de Janeiro: FGV. 2012.

- Representantes de quem? Os (des)caminhos do seu voto da urna à Câmara dos Deputados. Rio de Janeiro: Zahar, 2017. 
NORRIS, Pippa. "Cultural Explanations of Electoral Reform: A Policy Cycle Model". West European politics, 2010, vol. 34, no 3.

PEREIRA, C.; MUELLER, B. "Regras eleitorais e poderes do presidente no Congresso: duas dimensões complementares da capacidade governista". In: SOARES, Gláucio Ary; RENNO, Lúcio. (orgs.) Reforma política: lições da história recente. Rio de Janeiro: Fundação Getulio Vargas, 2006.

RAE, Douglas W. The political consequences of electoral laws. New Haven: Yale University Press, 1967.

RENWICK, Alan. The politics of electoral reform: Changing the rules of democracy. Cambridge: Cambridge University Press, 2010.

RENWICK, Alan; PILET, Jean-Benoit. The Personalization of Electoral Systems in Europe. Oxford: University Press, 2016.

SANTOS, Fabiano. "Instituiç̃es eleitorais e desempenho do presidencialismo no Brasil". Dados - Revista de Ciências Sociais, 1999, vol. 42, no 1, pp. 111-138.

. O Poder Legislativo no presidencialismo de coalizão. Belo Horizonte: UFMG, 2003.

. "Em defesa do presidencialismo de coalizão". In: SOARES, Gláucio Ary; RENNÓ, Lúcio. (orgs.). Reforma política: lições da história recente. Rio de Janeiro: Fundação Getúlio Vargas, 2006.

SHUGART, Matthew S. "Electoral 'efficiency' and the move to mixed-member systems". Electoral Studies, 2001a, vol. 20, no. 3, pp.173-193.

. "'Extreme' Electoral Systems and the Appeal of the Mixed-Member Alternative". In: SHUGART; WATTENBERG (eds.). Mixed-Member electoral Systems: The Best of Both Worlds? Oxford: Oxford University Press, 2001b, p. 25-51.

SHUGART, Matthew $S$; WATTENBERG, Martin P. "Introduction: The electoral reform of the twenty-first century", In SHUGART; WATTENBERG (eds.). MixedMember electoral Systems: The Best of Both Worlds? Oxford, Oxford University Press, 2001a, pp. 1-6.

. "Conclusion: Are mixed-member electoral systems the best of both worlds?" In SHUGART; WATTENBERG (eds.). Mixed-Member electoral Systems: The Best of Both Worlds? Oxford, Oxford University Press, 2001b, pp. 571596. 

VOTAÇÃO

Eric Nogueira Andrade

TAAGEPERA, Rein; SHUGART, Matthew Soberg. Seats and Votes: The effects and determinants of electoral systems. New Haven: Yale University Press, 1989.

TSEBELIS, George. Nested games: Rational choice in comparative politics. Berkeley: University of California Press, 1990. 